\title{
Mechanical properties: wood lumber versus plastic lumber and thermoplastic composites
}

\author{
Propriedades mecânicas: madeira versus madeira plástica \\ e compósitos termoplásticos
}

\section{Bernardo Zandomenico Dias Cristina Engel de Alvarez}

\begin{abstract}
$\mathbf{P}$

lastic lumber and thermoplastic composites are sold as alternatives to wood products. However, many technical standards and scientific studies state that the two materials cannot be considered to have the same structural behaviour and strength. Moreover, there are many compositions of thermoplastic-based products and plenty of wood species. How different are their mechanical properties? This study compares the modulus of elasticity and the flexural, compressive, tensile and shear strengths of such materials, as well as the materials' specific mechanical properties. It analyses the properties of wood from the coniferae and dicotyledon species and those of commercialized and experimental thermoplastic-based product formulations. The data were collected from books, scientific papers and manufacturers' websites and technical data sheets, and subsequently compiled and presented in Ashby plots and bar graphs. The high values of the compressive strength and specific compressive and tensile strengths perpendicular to the grain (width direction) shown by the experimental thermoplastic composites compared to wood reveal their great potential for use in compressed elements and in functions where components are compressed or tensioned perpendicularly to the grain. However, the low specific flexural modulus and high density of thermoplastic materials limit their usage in certain civil engineering and building applications.

Keywords: Polymer composite. Strength. Specific property. Density. Material selection.

Bernardo Zandomenico Dias Faculdades Multivix São Mateus - ES - Brasil

Cristina Engel de Alvarez Universidade Federal do Espírito Vitória - ES - Brasil

Recebido em 06/01/16 Aceito em 06/09/16

\section{Resumo}

A madeira plástica e os compósitos termoplásticos são vendidos como alternativas à madeira. Entretanto, normas técnicas e estudos científicos afirmam que não se pode considerar que os dois materiais tenham o mesmo comportamento estrutural e resistência. Além disso, existem muitas composições de madeira plástica e de compósitos termoplásticos e centenas de espécies de madeira. Quão diferentes são suas propriedades mecânicas? Este estudo compara o módulo de elasticidade e a resistência à flexão, à compressão, à tração e ao cisalhamento de tais materiais, assim como suas propriedades mecânicas específicas. São analisadas as propriedades de madeiras de árvores coníferas e dicotiledôneas e de madeira plástica e compósitos termoplásticos comercializados e experimentais. Os dados foram retirados de livros, artigos científicos, websites e documentos técnicos de fabricantes e apresentados em gráficos de Ashby e de barras. Os altos valores de resistência à compressão e de resistência específica à tração e à compressão perpendicular às fibras exibidos pelos compósitos experimentais comparados à madeira revelam seu potencial para uso em elementos comprimidos e sob compressão ou tração perpendicular às fibras. Porém, o baixo módulo de elasticidade específico e a elevada densidade dos produtos feitos com termoplásticos limitam sua aplicação na construção civil.

Palavras-chaves: Compósito polimérico. Resistência. Propriedade específica. Densidade. Seleção de material.
\end{abstract}




\section{Introduction}

The product commercially known as plastic lumber can be exclusively made of plastics or can be a plastic composite (CARROLL et al., 2001). In both cases, it is manufactured with the dimensions (BOLIN; SMITH, 2011; BAJRACHARYA et al., 2014) of and for similar uses as wood lumber (CARROLL et al., 2001; BENTHIEN; THOEMEN, 2012; BAJRACHARYA et al., 2014). Currently, plastic lumber is primarily produced based on thermoplastic matrices (NAJAFI; HAMIDINA; TAJVIDI, 2006; KLYOSOV, 2007) and is mainly used for compound benches, tables, decks, building facade coverings, pergolas and piers, and elements and structures that are commonly built from wood lumber.

There is a trend to continued market growth of plastic lumber and wood-plastic composites (a type of plastic composite produced with wood particles as filler), both in North America and in Europe (BOWYER et al., 2010). In 1995, approximately 50 thousand tonnes of them were consumed in both regions. In 2002, 600 thousand tonnes were consumed in North America and about 650 thousand tonnes in Europe, while in 2009, about 1000 and 1150 thousand tonnes were consumed, respectively, in such places (BOWYER et al., 2010). Regarding solely wood-plastic composites, there is a global production growth trend (CARUS et al., 2014), where it is primarily used for decking (CARUS et al., 2014; HAIDER; EDER, 2010). Specifically in 2010 and 2012, the European, North American and South American production reached 220 and 260, 900 and 1100, and 10 and 20 thousand tonnes, respectively (CARUS et al., 2014).

Manufacturers sell plastic lumber products, claiming they are more durable, safer and need less maintenance than wood products and can therefore effectively be substituted into non-structural or semi-structural components. In addition, because plastic lumber is commonly manufactured from residues and post-consumer plastics, its use minimizes the amount of trash going to landfills and the need for virgin material (NAJAFI; HAMIDINA; TAJVIDI, 2006; BAJRACHARYA et al., 2014), so manufacturers also market their products as environmentally superior to wood lumber.

A life cycle assessment (LCA) of alkaline copper quaternary (ACQ)-treated lumber in comparison to wood plastic composite (WPC) decking shows that the latter has a significantly higher environmental impact than the former (BOLIN; SMITH, 2011). Nevertheless, in terms of durability and maintenance, studies have shown that plastic lumber provides a better performance than wood lumber (WINANDY; STARK; CLEMONS, 2004; GARCÍA et al., 2009; AZWA et al., 2013; NDIAYE; GUEYE; DIOP, 2013; WEI et al., 2013) and are also economically advantageous in the long term, as their maintenance can be performed less regularly and using simple products, such as soap and water. Plastic-based products also absorb less water (STARK, 2005; CHEVALI; DEAN; JANOWSKI, 2010; NAJAFI; KORDKHEILI, 2011; BENTHIEN; THOEMEN, 2012; LEU et al., 2012; AZWA et al., 2013; CHAVOOSHI et al., 2014; YOUSSEF; ELGENDY; KAMEL, 2015), which contributes to a longer useful life, as effects such as swelling (KLYOSOV, 2007), component buckling (KLYOSOV, 2007), decrease in mechanical strength (STARK, 2006; STRÖMBERG; KARLSSON, 2009; MORRELL et al., 2010; NAJAFI; KORDKHEILI, 2011) and biological degradation (STRÖMBERG; KARLSSON, 2009; HEMMATI; GARMABI, 2012; NAUMANN; STEPHAN; NOLL, 2012; AZWA et al., 2013) are minimized. However, can they really substitute wood lumber products? The two types of materials (wood lumber and plastic lumber) have very different mechanical properties.

Affirming generically that wood lumber is more or less strong or stiff than plastic lumber and thermoplastic-based composites is incorrect, and using plastic lumber as an alternative for wood lumber is not simple, considering the wide variety of wood species and compositions of thermoplastic-based products. The simple difference between the mechanical properties of wood and plastic lumber makes their components distinct in terms of dimensions, volume and mass, as well as in terms of the amount of elements used in a specific situation, such as a deck substructure.

Thus, the aim of this study was to compare the density, the modulus of elasticity (flexural modulus), and the static flexural, compressive, tensile and shear strengths of wood from coniferae and dicotyledon species from the Northern and Southern Hemispheres with the equivalent properties of commercialized and experimental thermoplastic-based product formulations. This research also intended to compare the materials' specific mechanical properties (mechanical property to density ratio).

Because there are many variables that affect the mechanical properties of thermoplastic products, such as the method of manufacture (injection moulding or extrusion), the wood species used to 
produce the lignocellulosic fillers, and the testing procedures, the proposal of this paper is not to compare particular values, but rather to provide general mechanical properties, showing, using plots, the area in which such materials reside.

\section{Methods}

Data were collected from the literature on 57 coniferae and 183 dicotyledon wood species, also known as softwoods and hardwoods, respectively, from the Northern and Southern Hemispheres. Additionally, data on 25 commercialized plastic lumber compositions were obtained from manufacturer's websites and technical guides and other literature. Data on 146 polymeric and composite experimental formulations were from in scientific papers. Some materials' density and mechanical strength values were collected from graphs contained within the papers analysed, as some of them did not present tables with the exact values of the properties. Thus, some of the values showed in and plotted in the graphs of this paper may not be the same as those of the original research, but rather they are close approximations.

The static mechanical properties of the materials were compared using Ashby plots (ASHBY, 2005) and bar graphs. The Ashby plots relate the density of each material to its respective mechanical properties. The properties studied were the modulus of elasticity (flexural modulus), flexural strength, compressive strength parallel and perpendicular to the grain, tensile strength parallel and perpendicular to the grain, and shear strength. In turn, bar graphs were used to compare the materials' specific mechanical properties, such as specific flexural modulus and strength.

\section{Technical standards used in mechanical tests on the analysed materials}

Mechanical data were collected from studies that used different standards to obtain values for the materials' density, modulus of elasticity and strength. In the case of experimental thermoplastic products developed by researchers, the tensile properties were measured in all studies using ASTM D638 (AMERICAN..., 2014a), but the flexural properties were measured a variety of standards such as ASTM D143 (AMERICAN..., 2014b), ASTM D4761 (AMERICAN..., 2013) and ASTM D6272 (AMERICAN..., 2010a), although most used ASTM D790 (AMERICAN..., 2010b). The same phenomenon was observed for commercialized thermoplastic products' flexural properties, as well as their tensile, compressive and shear properties. Different data have also been collected from different books for some wood species. Thus, as some variation of the strength values may occur when a material is tested using different technical standards, the goal of this paper is not to compare exact values but rather general mechanical properties, showing in the plots the areas in which the properties of such materials reside.

\section{Thermoplastic-based products' compressive and tensile strength parallel (direction of length) and perpendicular (direction of width) to the grain}

When papers did not clearly presented the composites' density values, they were unappreciated in this study, even though the percentage and density of each material in the composites' formulation were described. Since many factors and procedures in the manufacturing process can change the density of the produced materials, it was considered that applying a simple rule-of-mixture to calculate the composites' densities would lead to unreal values.

In turn, none of the analysed papers, books or manufacturers' websites provided data on all the static mechanical properties analysed in this research. Therefore, the analysis and graphs presented for each property covered in the Results section do not embrace all the considered wood species and thermoplastic-based product compositions. However, when the papers or manufacturers presented only the strength parallel or perpendicular to the grain, it was considered that both values were equal, for compressive and tensile strength.

This assumption was made because the materials used to compound a thermoplastic composite or plastic lumber - plastic, lignocellulosic and/or mineral filler(s) and additives - are generally mixed with no concern for the orientation of the fibres, when glass or wood fibres are used, for example, although the fibre orientation can have a huge influence on the composites' mechanical properties (JOSEPH et al., 2002; MIGNEAULT et al., 2009; YOO; SPENCER; PAUL, 2011; SINGH et al., 2014; VÄNTSI; KÄRKI, 2014). Among the 20 analysed papers, none provide procedures for the production of fibre-oriented composites in the preparation of the tested samples. Thus, for this type of material whose fibres are randomly oriented in many directions during the manufacturing process, the distinction between 
strengths parallel and perpendicular to the grain makes no sense.

\section{Thermoplastic-based product compositions}

The range of thermoplastic product compositions analysed is wide. It includes specimens made of pure virgin or recycled high-density polyethylene (HDPE), low-density polyethylene (LDPE), polypropylene (PP) and acrylonitrile butadiene styrene (ABS). It also includes composites that mix such plastics with fillers such as wood flour, wood fibre, bark fibre, rice hulls, hemp fibre, flax fibre, sugarcane bagasse fibre, calcium carbonate, carbonized and uncarbonized cow bone powder, silica fume, kaolin, talc, and glass fibres and with additives such as coupling agents and lubricants. There are also variations in the percentages of each component used.

In addition, the wood species from which the wood flour and wood fibre are produced may differ from reference to reference. Some wood species used to compound the thermoplastic products tested in the analysed papers are Pinus radiata (ADHIKARY; PANG; STAIGER, 2008; BEG; PICKERING, 2008), Populus deltoides (NOURBAKHSH; ASHORI, 2009), Cunninghamia lanceolate, Cryptomeria japonica, Taiwania crytomerioides (KUO et al., 2009), Pinus ponderosa, Quercus alba, Pseudotsuga menziesii, Gleditsia triacanthos
(FABIYI; MCDONALD, 2010), Pinus nigra (BUYUKSARI; AYRILMIS; AKBULUT, 2012) and Populus tremuloides (YEMELE et al., 2010). Some papers, such as Adhikary et al. (2011) and Leu et al. (2012), used wood flour from many wood species belonging to the same genus to produce the WPCs.

\section{Results}

A comparison between the mechanical properties of the wood lumber species and those of the plastic lumber and wood plastic composite materials is presented in the subsections below.

\section{Modulus of elasticity (flexural modulus)}

The highest values of the modulus of elasticity among the thermoplastic products were found in PP-, HDPE- and PVC-based composites, and all are in the same region, between $5000 \mathrm{MPa}$ and $9000 \mathrm{MPa}$, as the wood species' lowest values (Figure 1). When analysing only the commercialized thermoplastic products, the highest flexural modulus is close to $6000 \mathrm{MPa}$, close to the five lowest wood species' flexural modulus among the 195 species analysed for this property.

Figure 1 - Ashby plot presenting the modulus of elasticity vs. the density for various wood species and thermoplastic products

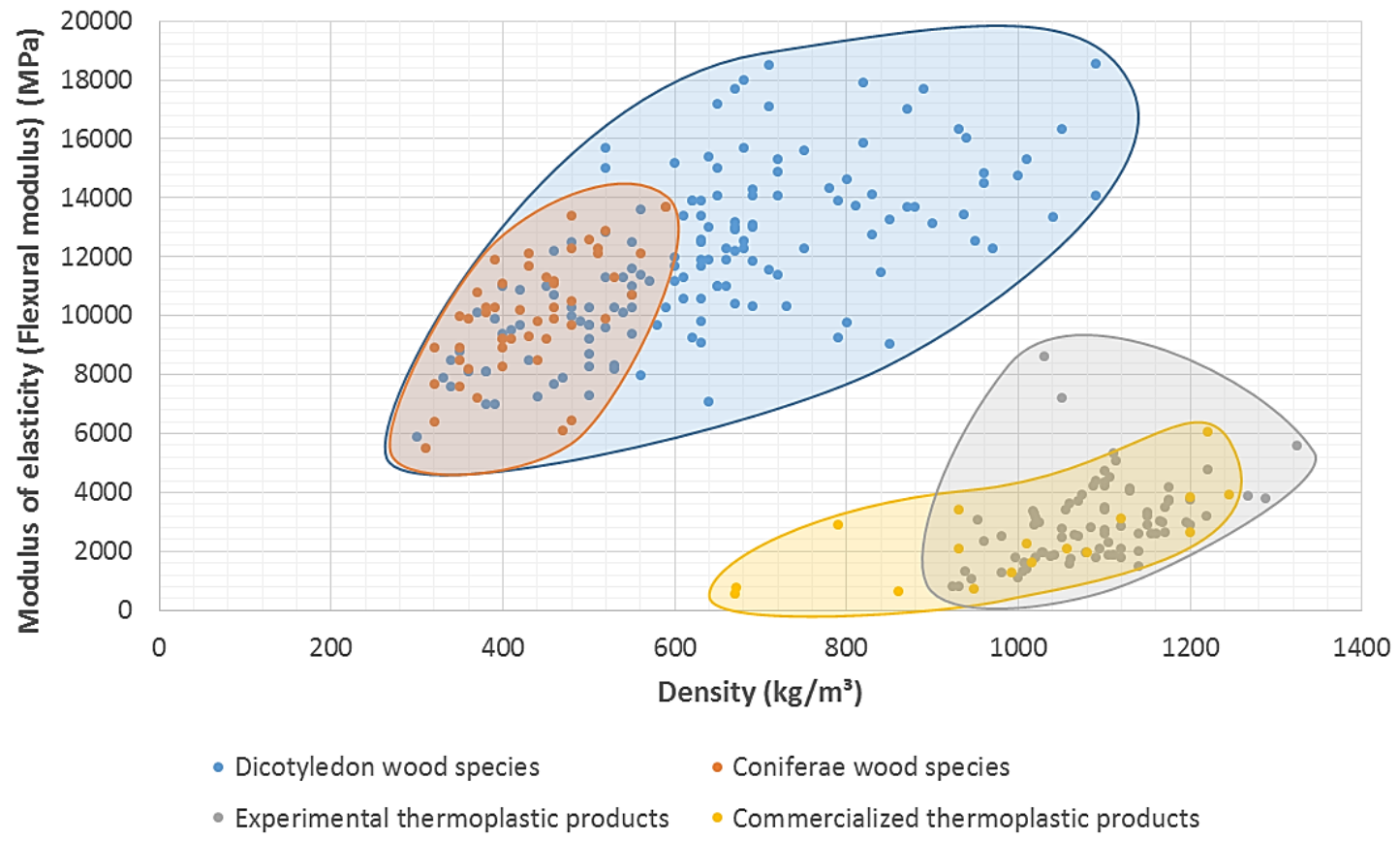

204 Dias, B. Z.; Alvarez, C. E. de 
The thermoplastic products that exhibited values of the modulus of elasticity comparable to those of the wood species have a much higher, as can be observed on the specific flexural modulus graph (Figure 2). Moreover, none of the thermoplasticbased products have a specific flexural modulus that is higher than that of any wood species, even comparing the highest values of the former $(8359$ $\mathrm{MPa} / \mathrm{g} / \mathrm{cm}^{3}$ and $4967 \mathrm{MPa} / \mathrm{g} / \mathrm{cm}^{3}$ for experimental and commercialized products, respectively) to the lowest of the latter $\left(12978 \mathrm{MPa} / \mathrm{g} / \mathrm{cm}^{3}\right.$ and 10648 $\mathrm{MPa} / \mathrm{g} / \mathrm{cm}^{3}$, for coniferae and dicotyledon species, respectively). The highest specific flexural modulus values for the experimental thermoplastic products were also found in PP-, HDPE- and PVCbased composites.

\section{Flexural strength}

The highest values of flexural strength among the thermoplastic products are in the same region, between approximately $80 \mathrm{MPa}$ and $120 \mathrm{MPa}$, as the highest flexural strength values of the coniferae wood species and the average values of the dicotyledon wood species (Figure 3). If analysing only the commercialized thermoplastic products, the highest flexural strength is close to $40 \mathrm{MPa}$. Only the experimental thermoplastic products considerably exceeded that value: the highest flexural strength value found for this type of material was $119 \mathrm{MPa}$, reached by a composite made from PP, carbonized cow bone powder and lubricant, investigated by Asuke et al. (2012). In fact, a pure ABS product and nylon (6 and 66)based and PP-carbonized cow bone powder composites reached the highest thermoplastic flexural strengths. All other plastic products analysed (PP-, HDPE- and LDPE-based) reached maximum flexural values between approximately $50 \mathrm{MPa}$ and $70 \mathrm{MPa}$. It has been found in literature PP-wood flour and PP-wood fiber composites that reached static flexural strength over than $80 \mathrm{MPa}$ (NDIAYE; GUEYE; DIOP, 2013) and 90MPa (KARMARKAR et al., 2007), respectively, while (KIM et al., 2008) presents PP-cotton fiber composites that reached more than 200MPa; however as the composites' density values were not presented in the papers, the data were not considered in this study.

PP-carbonized cow bone powder and PPuncarbonized cow bone powder exhibited the highest specific strength, followed by nylon composites. Similar to the flexural modulus, the thermoplastic products that exhibited values of flexural strength comparable to those of wood have a much higher density. This aspect can be seen in Figure 4.

Figure 2 - Specific modulus of elasticity of various wood species and thermoplastic products

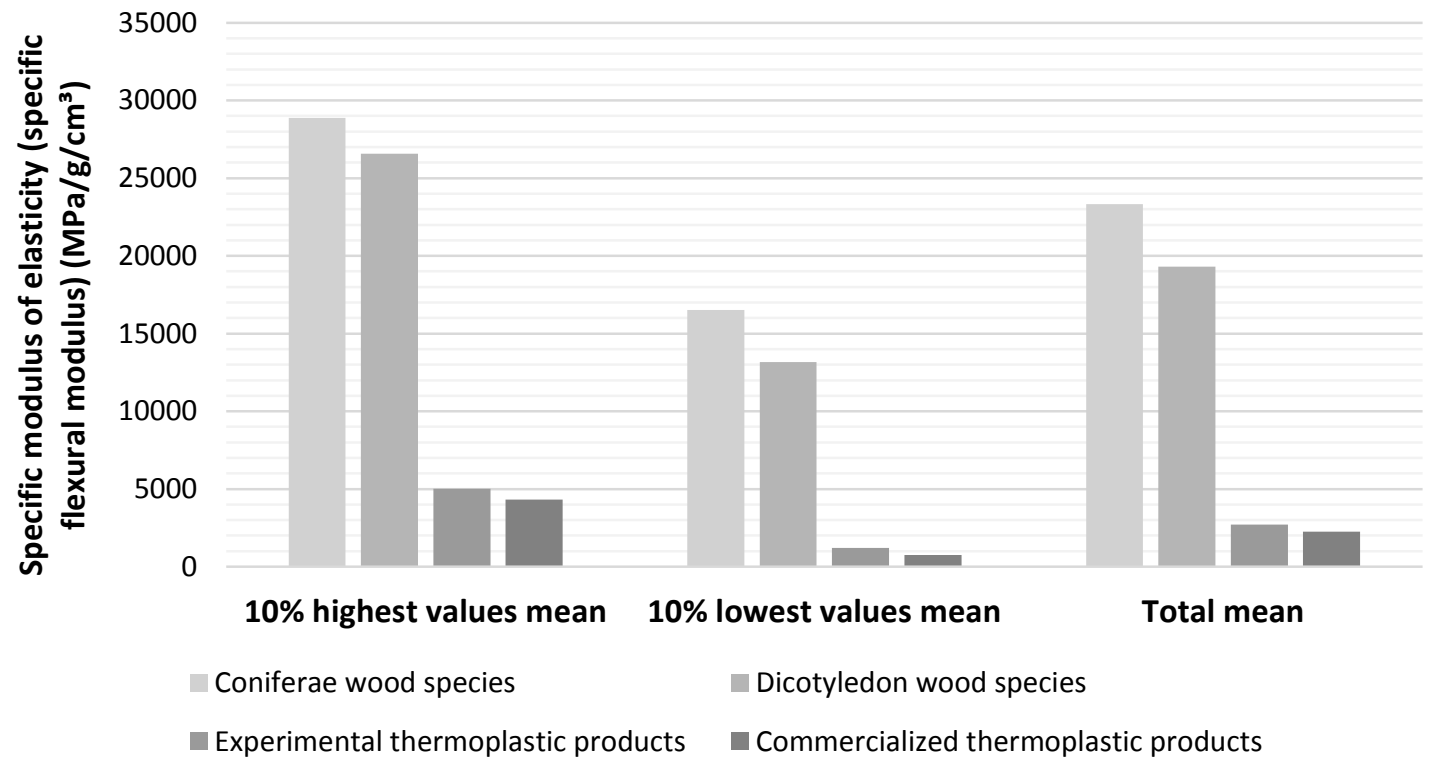

Note: the mean of the $10 \%$ highest values, the mean of the $10 \%$ lowest values and the total mean of the materials' specific flexural strength were calculated using data from 50 coniferae wood species, 145 dicotyledon wood species, 83 experimental thermoplastic product compositions from 14 different papers and 17 commercialized thermoplastic product compositions from 12 manufacturers. 
Figure 3 - Ashby plot presenting the flexural strength vs. the density of various wood species and thermoplastic products

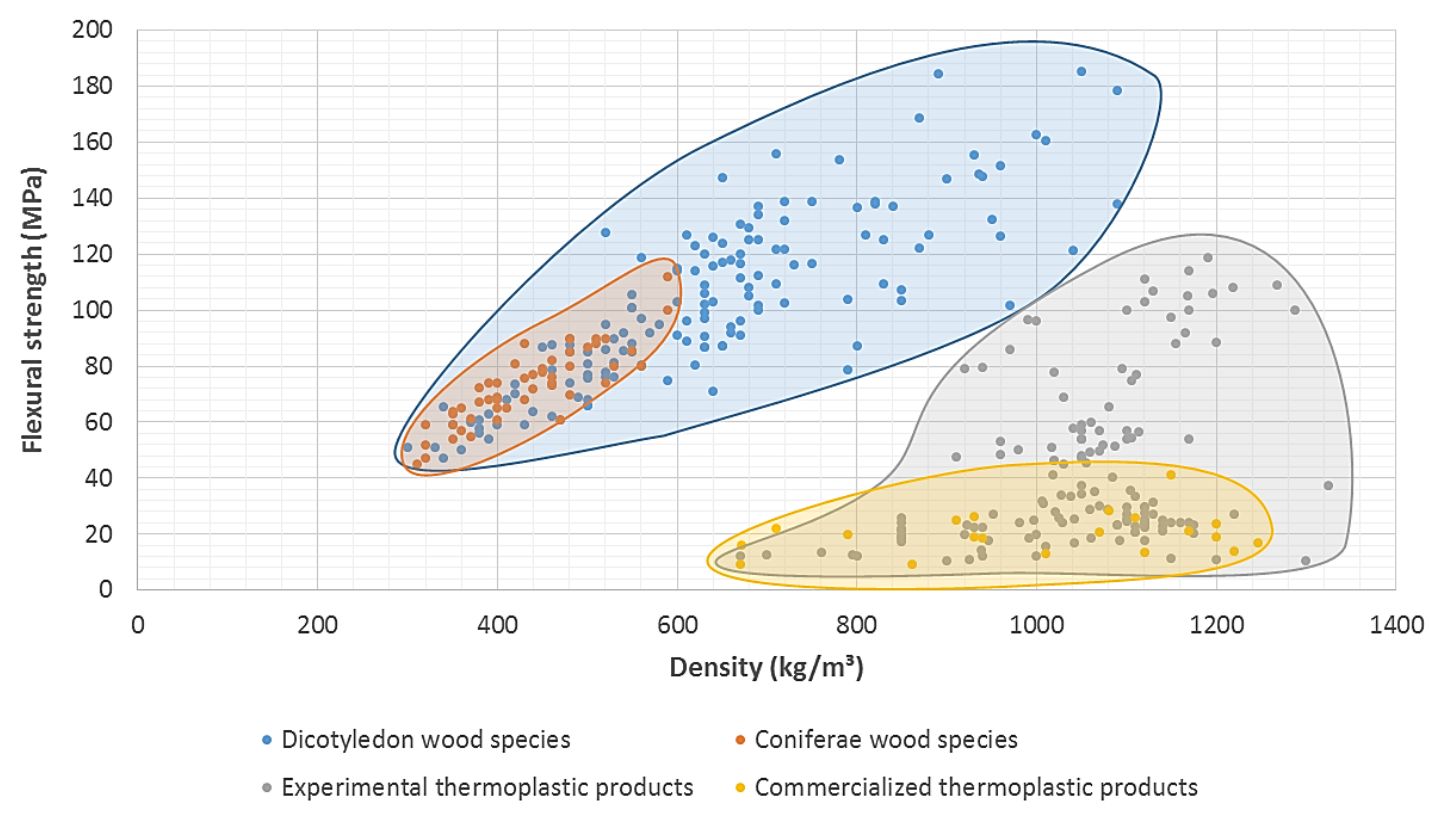

Figure 4 - Specific flexural strength of various wood species and thermoplastic products

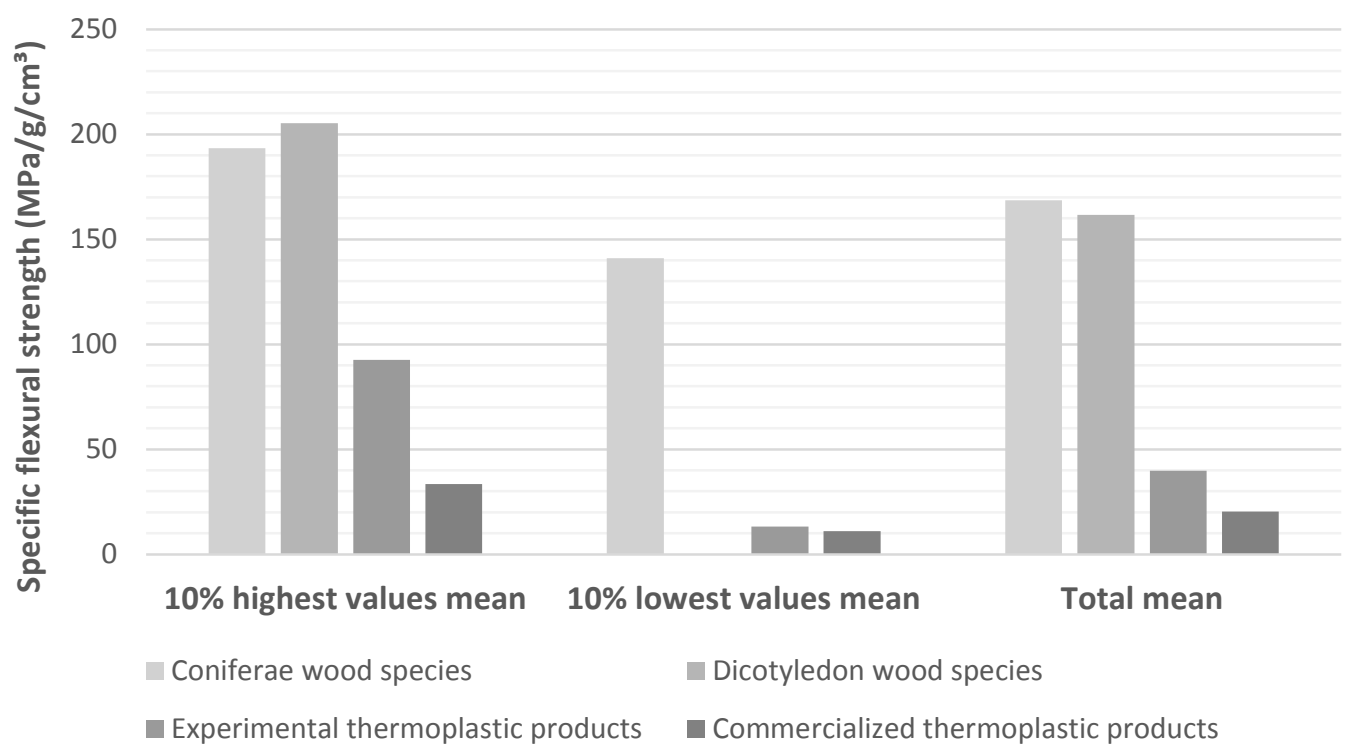

Note: the means of the materials' specific flexural strength were calculated using data from 50 coniferae wood species, 145 dicotyledon wood species, 141 experimental thermoplastic product compositions from 19 different papers and 20 commercialized thermoplastic product compositions from 18 manufacturers.

\section{Tensile strength parallel to the grain}

Only one thermoplastic-based material produced by a manufacturer has a tensile strength parallel to the grain similar to that of some wood species and, specifically, to the average of the coniferae species (about 67MPa); all other commercialized thermoplastic products have inferior tensile strengths parallel to the grain (Figure 5). Among the experimental thermoplastic products, strength values above $50 \mathrm{MPa}$ were reached by nylon-based composites, while PP-, HDPE- and LDPE-based composites reached maximums of approximately $40 \mathrm{MPa}, 35 \mathrm{MPa}$ and $30 \mathrm{MPa}$, respectively. Some papers described $\mathrm{PP} /$ wood flour/fire retardants (ARAO et al., 2014), PP/talc/wood flour (GWON et al., 2010) and PP-wood fiber and PP-cotton 
fiber (KIM et al., 2008) composites as having static tensile strength parallel to grain close to $50 \mathrm{MPa}$, while another article showed a recycled HDPE-hemp fiber composite with tensile strength equal to $60 \mathrm{MPa}$ (LU; OZA, 2013). However, as the composites' density values were not presented in the papers, the data were not considered in this study.

Both coniferae and dicotyledon wood species have specific tensile strengths parallel to the grain that are much higher than those of thermoplastic products (Figure 6). Polymer composites (HDPE (BEDFORD..., 2015) and various plastics (ECOTECH..., 2006)) made with glass fibres and additives and nylon-based products and composites (filled with plant fibres (OZEN et al., 2013), microcrystalline cellulose (KIZILTAS et $a l ., 2014)$ and silica fume (RAJA; KUMARAVEL, 2015)) exhibited the highest thermoplastic specific strength values for the commercialized and experimental products, respectively.

Figure 5 - Ashby plot presenting the tensile strength parallel to the grain vs. the density for various wood species and thermoplastic products

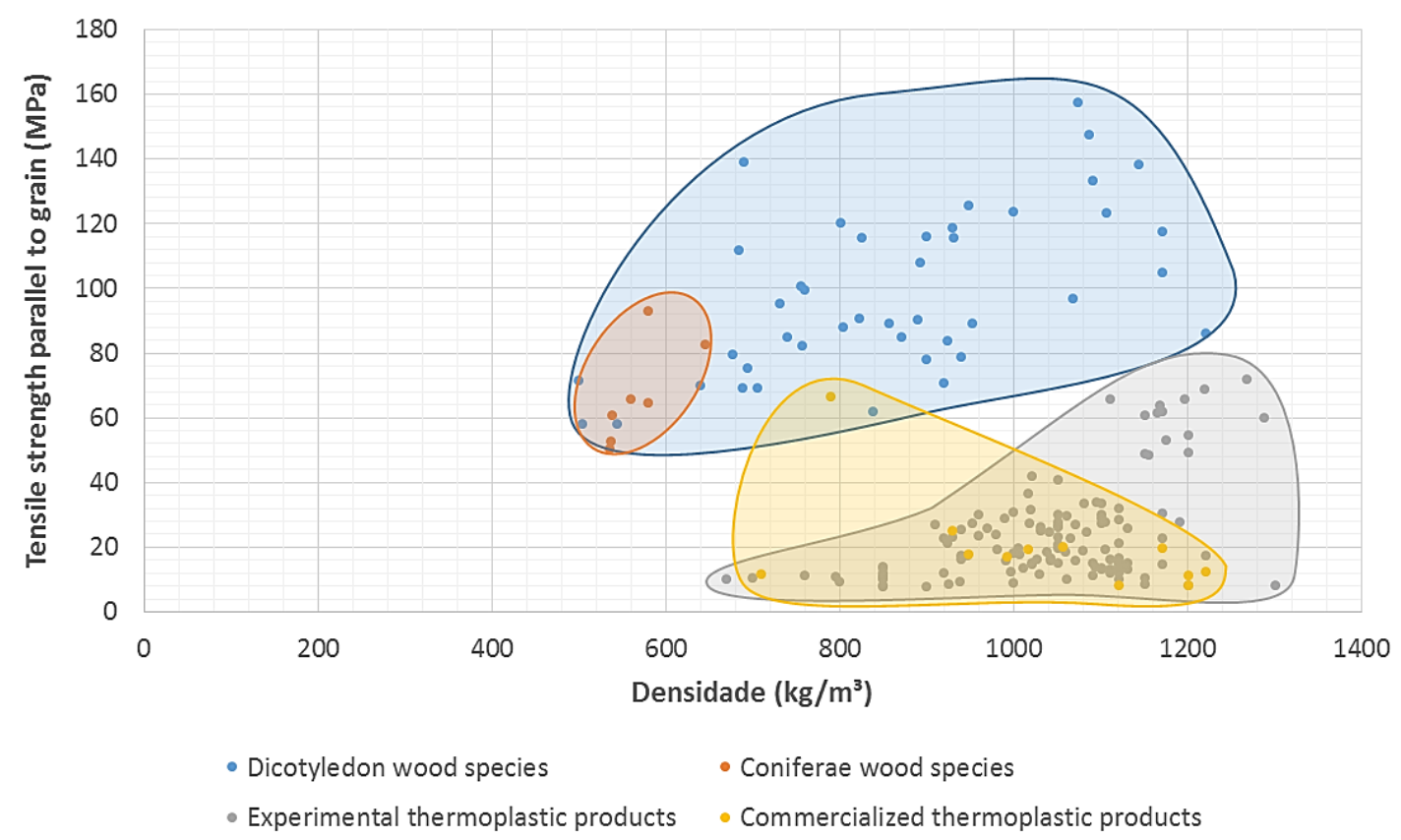

Figure 6 - Specific tensile strength parallel to the grain for various wood species and thermoplastic products

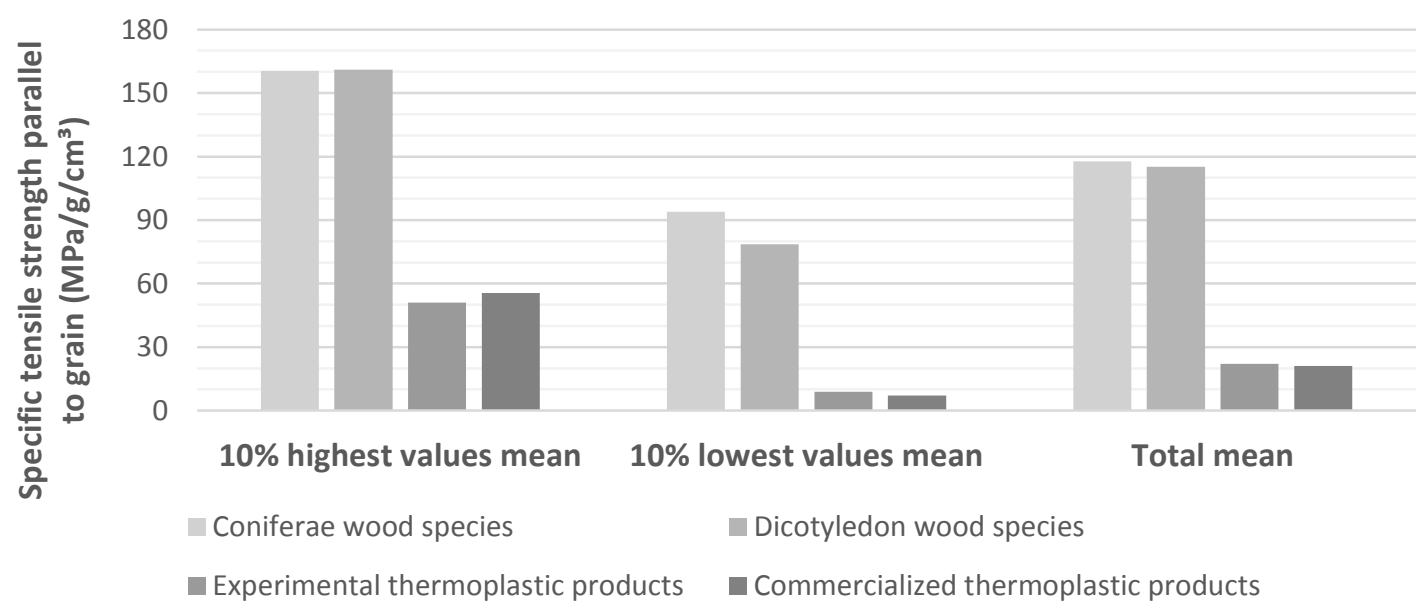

Note: the means of the materials' specific flexural strengths were calculated using data from 7 coniferae wood species, 43 dicotyledon wood species, 127 experimental thermoplastic product compositions from 17 different papers, and 12 commercialized thermoplastic product compositions from 9 manufacturers. 


\section{Tensile strength perpendicular to the grain}

Researchers studying thermoplastic composites and manufacturers of this type of material rarely measure the tensile strength perpendicular to the grain. In addition, it was considered that the strength perpendicular and parallel to the grain tend to be very similar in thermoplastic products. Thus, the thermoplastic strength values used to generate the Ashby plot (Figure 7) and bar graph (Figure 8) for the tensile strength perpendicular to grain are practically the same as those used to generate the Ashby plot (Figure 5) and bar graph (Figure 6) of the tensile strength parallel to the grain, with few exceptions.

Figure 7 shows that the lowest values of the tensile strength perpendicular to the grain belong to coniferae wood species and some dicotyledon wood species. Many experimental thermoplastic products exhibited extremely high strengths. The nylon-based composites have the highest strength, exceeding $70 \mathrm{MPa}$. On the other hand, some experimental products have strengths in the range of dicotyledon wood, i.e., below $14 \mathrm{MPa}$. Many commercialized thermoplastic products have higher tensile strengths perpendicular to the grain than wood, but a few are also in the range of the dicotyledon wood species.

Approximately $84 \%$ of the analysed dicotyledon wood species present densities below $900 \mathrm{~kg} / \mathrm{m}^{3}$, while approximately $91 \%$ of the analysed thermoplastic products have densities above 900 $\mathrm{kg} / \mathrm{m}^{3}$. However, the experimental thermoplastic products show greatly superior strengths. Therefore, they have higher specific tensile strengths perpendicular to the grain (Figure 8).

\section{Compressive strength parallel to the grain}

Few papers were found that presented the compressive strength of thermoplastic products. In addition, some papers that contained these data lacked values for the composites' density. Only two papers ((ASUKE et al., 2012; RAJA; KUMARAVEL, 2015)) were found that provided both types of information for thermoplastic-based composites.

Figure 9 shows that the commercialized thermoplastic products have the lowest compressive strength parallel to the grain. Nevertheless, its highest strength values, between $25 \mathrm{MPa}$ and $50 \mathrm{MPa}$, are similar to those of many coniferae and dicotyledon wood species. On the other hand, experimental plastic-based products have significantly higher compressive strengths parallel to the grain, reaching almost $200 \mathrm{Mpa}$. However, all of the experimental plastic-based products whose data are plotted in Figure 9 are pure nylon products (RAJA; KUMARAVEL, 2015), nylon-silica fume composites (RAJA; KUMARAVEL, 2015), PP-carbonized cow bone powder (ASUKE et al., 2012) or PP-uncarbonized cow bone powder (ASUKE et al., 2012).

Figure 7 - Ashby plot presenting the tensile strength perpendicular to the grain vs. the density for various wood species and thermoplastic products

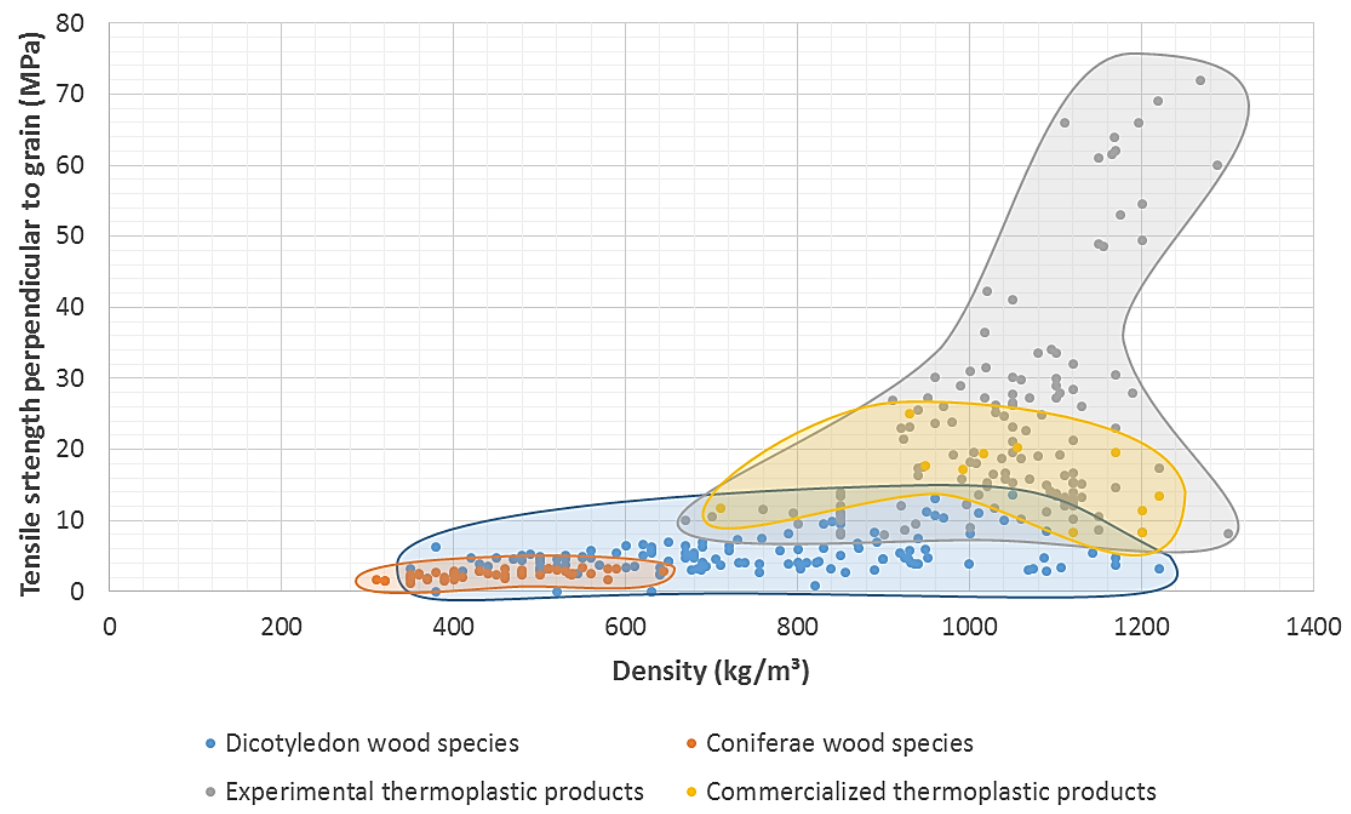

208 Dias, B. Z.; Alvarez, C. E. de 
Figure 8 - Specific tensile strength perpendicular to the grain for various wood species and thermoplastic products

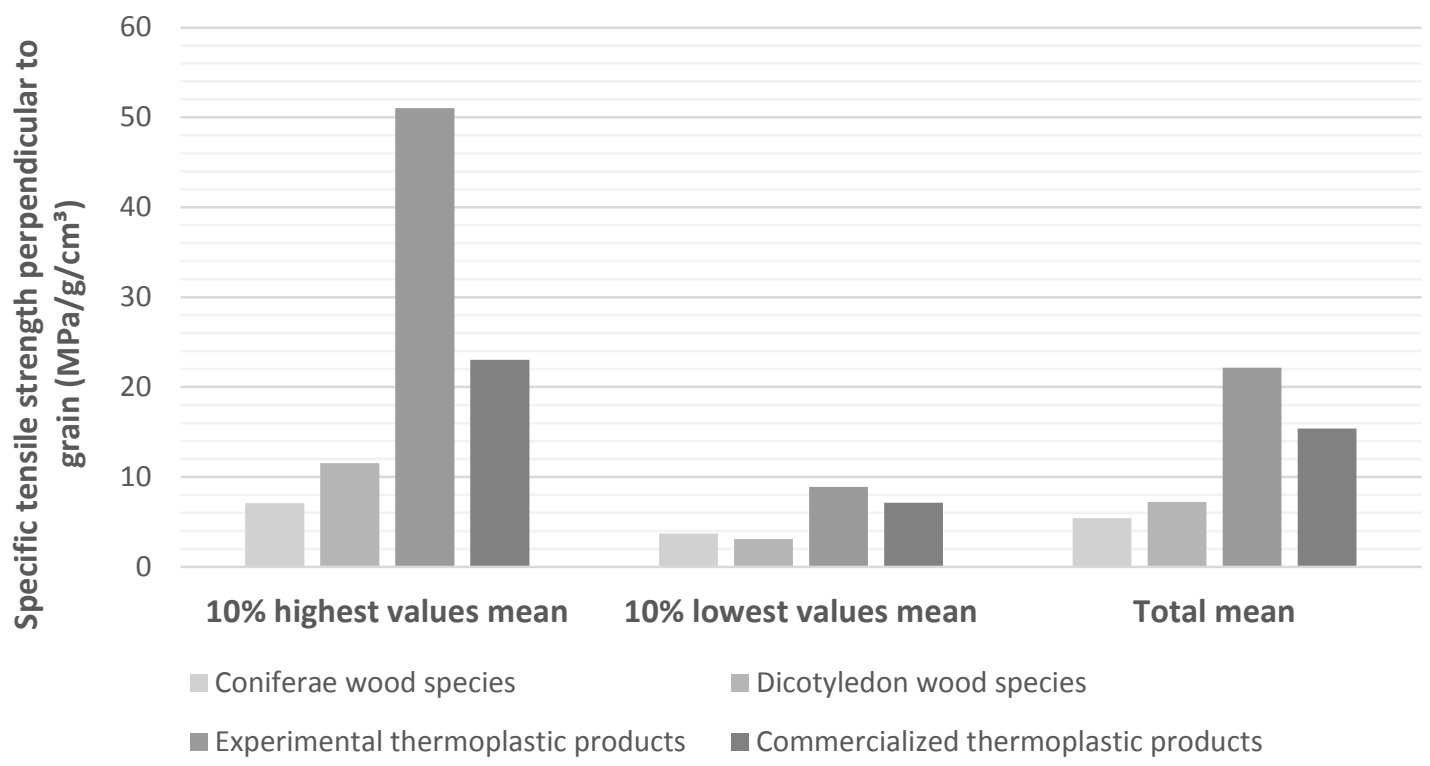

Nota: the means of the materials' specific flexural strengths were calculated using data from 44 coniferae wood species, 130 dicotyledon wood species, 127 experimental thermoplastic product compositions from 17 different papers, and 11 commercialized thermoplastic product compositions from 9 manufacturers.

Figure 9 - Ashby plot presenting the compressive strength parallel to the grain vs. the density for various wood species and thermoplastic products

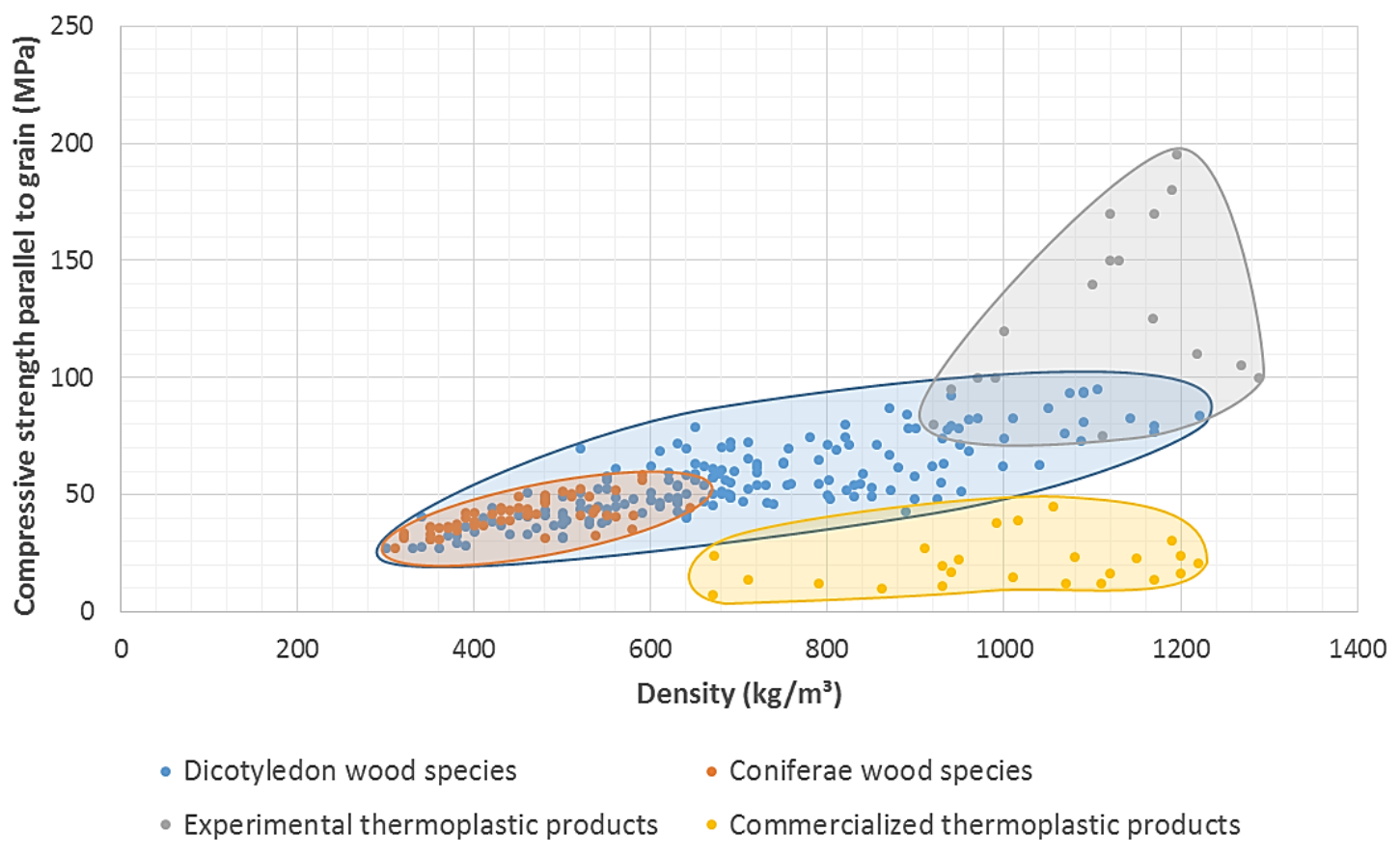

One study on composites made from various percentages of PP, wood fibre, microtalc and coupling agent shows compressive strengths ranging from approximately $20 \mathrm{MPa}$ to $30 \mathrm{MPa}$ (GARCÍA et al., 2009); another, on composites made from PP and mica, show compressive strengths ranging from approximately $25 \mathrm{MPa}$ to 40 MPa (OMAR; AKIL; AHMAD, 2011). An investigation on the compressive strength of recycled polyethylene (PE)- and LDPE-oyster shell powder composites presents strength values between approximately $3 \mathrm{MPa}$ and $7 \mathrm{MPa}$ 
(CHONG et al., 2006). However, these three studies did not measure the composite densities. (CARROLL et al., 2001) presents the composites' densities and compressive strength values, but the latter were measured only for extreme situations, such as very cold $\left(-23.3{ }^{\circ} \mathrm{C}\right)$ or hot days $\left(40.6{ }^{\circ} \mathrm{C}\right)$. Therefore, they were not considered in this analysis.

Although the means of Figure 10 are based on few data on experimental product compressive strengths, it shows that the mean of the $10 \%$ highest values of the experimental thermoplastic products' specific compressive strength parallel to the grain exceeds almost $45 \%$ of the wood species values. However, when the mean of the $10 \%$ lowest values and the total mean are analysed, the differences between the three types of material are lower. In general, the commercialized thermoplastic products are at least 2.5 times less efficient than the other materials.

\section{Compressive strength perpendicular to the grain}

As with the tensile strength perpendicular to the grain, the thermoplastic strength values used to generate the Ashby plot (Figure 11) and bar graph (Figure 12) are practically the same as those analysed in the section about the compressive strength parallel to the grain, with few exceptions.

Figure 11 shows that the lowest values of the tensile strength perpendicular to the grain belongs to coniferae and dicotyledon wood species and to some commercialized thermoplastic products. Experimental plastic-based products have the highest compressive strengths parallel to the grain, some almost as high as $200 \mathrm{MPa}$. Nonetheless, all experimental plastic-based product data plotted in Figure 11 are for a pure nylon product, nylon-silica fume composites, PP-carbonized cow bone powder, or PP-uncarbonized cow bone powder, as studied by Raja and Kumarave (2015) and Asuke et al. (2012). In turn, some commercialized thermoplastic products show a higher compressive strength perpendicular to the grain than wood.

Experimental products show the highest specific strength (Figure 12). Commercialized products have a higher specific strength than the coniferae and dicotyledon wood species, but the results of these three groups are not so different.

\section{Figure 10 - Specific compressive strengths parallel to the grain of various wood species and thermoplastic products}

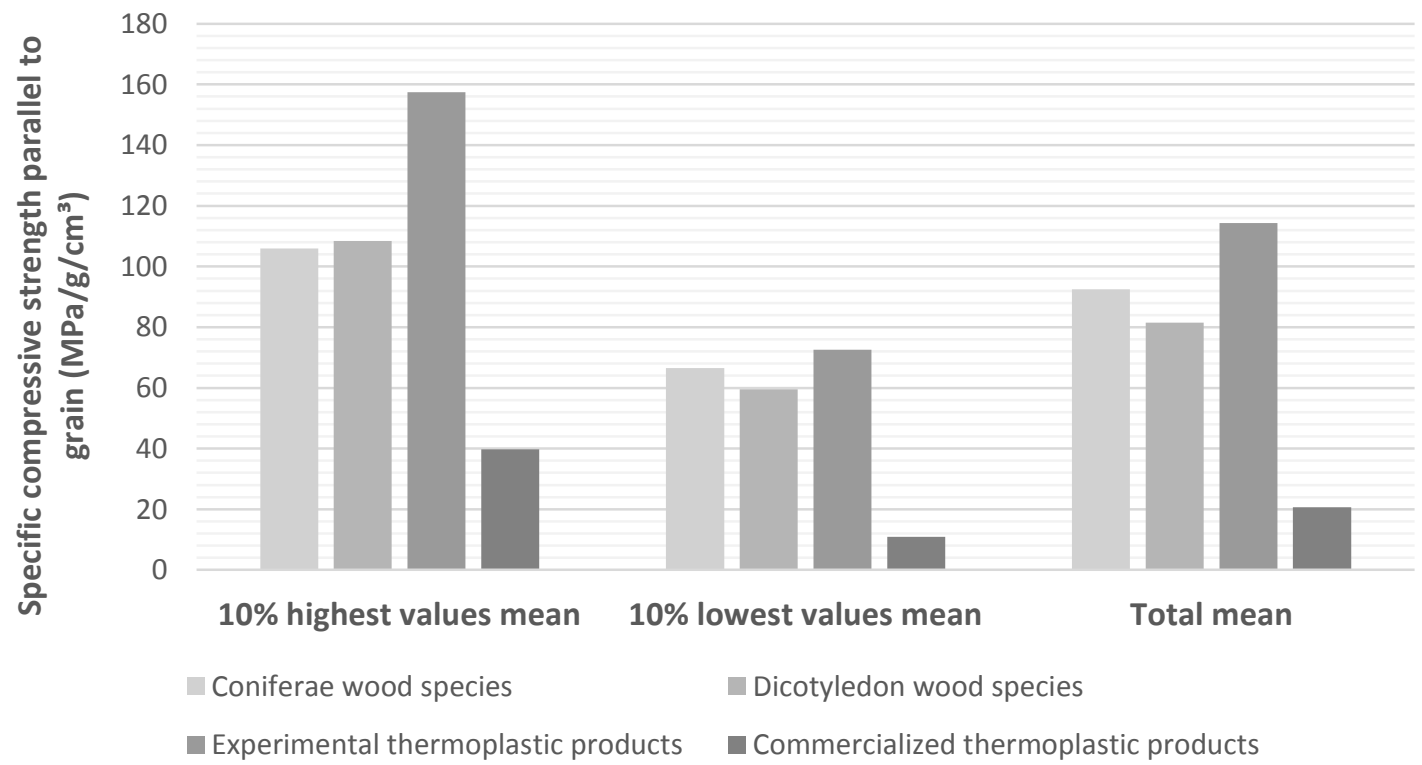

Note: the means of the materials' specific flexural strength were calculated using data from 57 coniferae wood species, 188 dicotyledon wood species, 17 experimental thermoplastic product compositions from 2 papers and 24 commercialized thermoplastic product compositions from 19 manufacturers. 
Figure 11 - Ashby plot presenting the compressive strength perpendicular to the grain vs. the density for various wood species and thermoplastic products

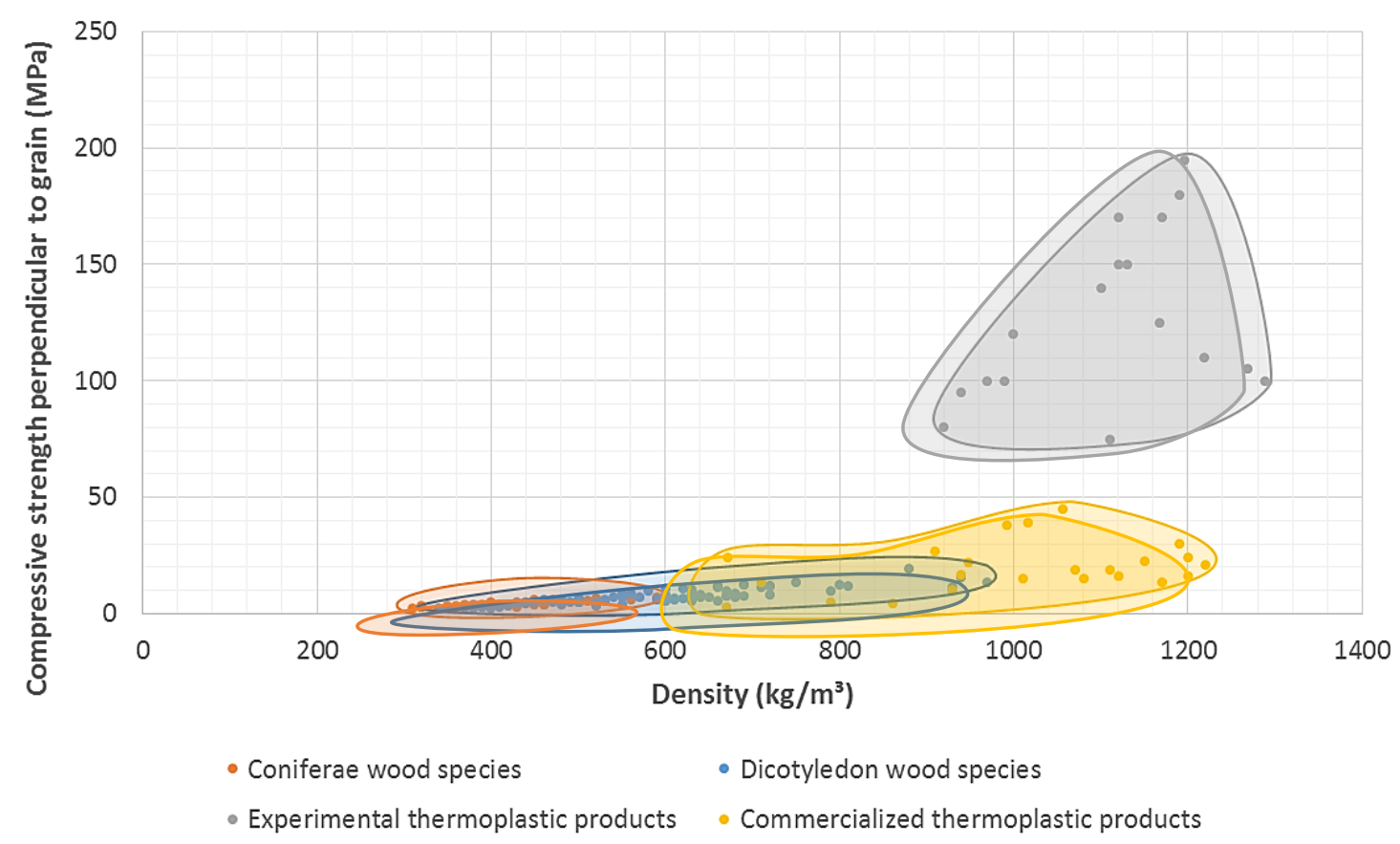

Figure 12 - Specific compressive strength perpendicular to the grain for various wood species and thermoplastic products

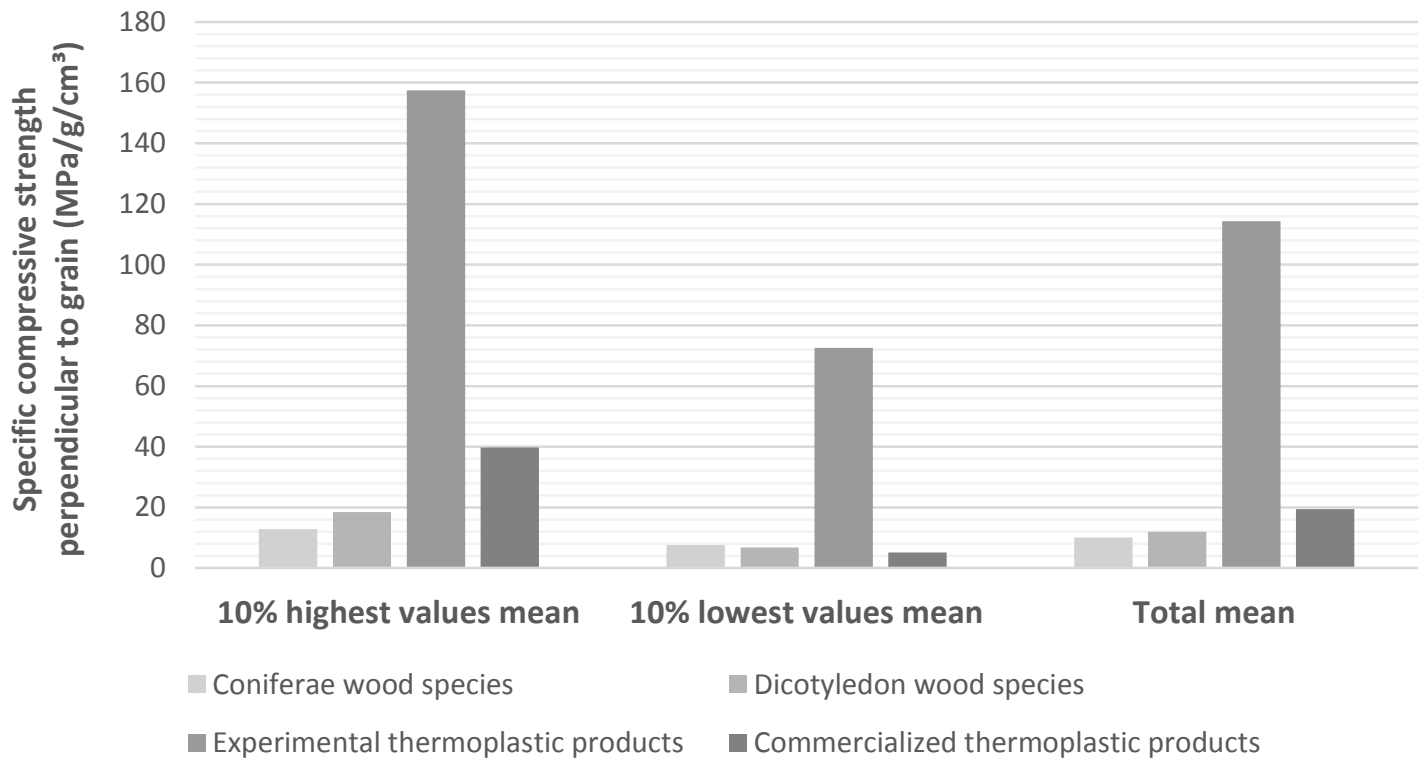

Note: the means of the materials' specific flexural strengths were calculated using data from 47 coniferae wood species, 75 dicotyledon wood species, 17 experimental thermoplastic product compositions from 2 papers, and 24 commercialized thermoplastic product compositions from 19 manufacturers. 


\section{Shear strength}

No papers measuring the shear strength of thermoplastic products were found. Of the 25 commercialized thermoplastic products analysed, such information was available for 6. However, based on the few data gathered on thermoplastic composite shear strengths, Figure 13 reveals that the values are in the same range as those of the wood species, between $5 \mathrm{MPa}$ and $19 \mathrm{MPa}$, although a few wood species exceed this value.

Figure 14 shows that the specific shear strengths of the coniferae and dicotyledon wood species are similar and that those of the commercialized thermoplastics were lower by a minimum of $60 \%$. The HDPE-additive product has the highest thermoplastic product shear strength to density ratio, $19 \mathrm{MPa} / \mathrm{g} / \mathrm{cm}^{3}$.

Figure 13 - Ashby plot presenting the shear strength vs. the density for various wood species and thermoplastic products

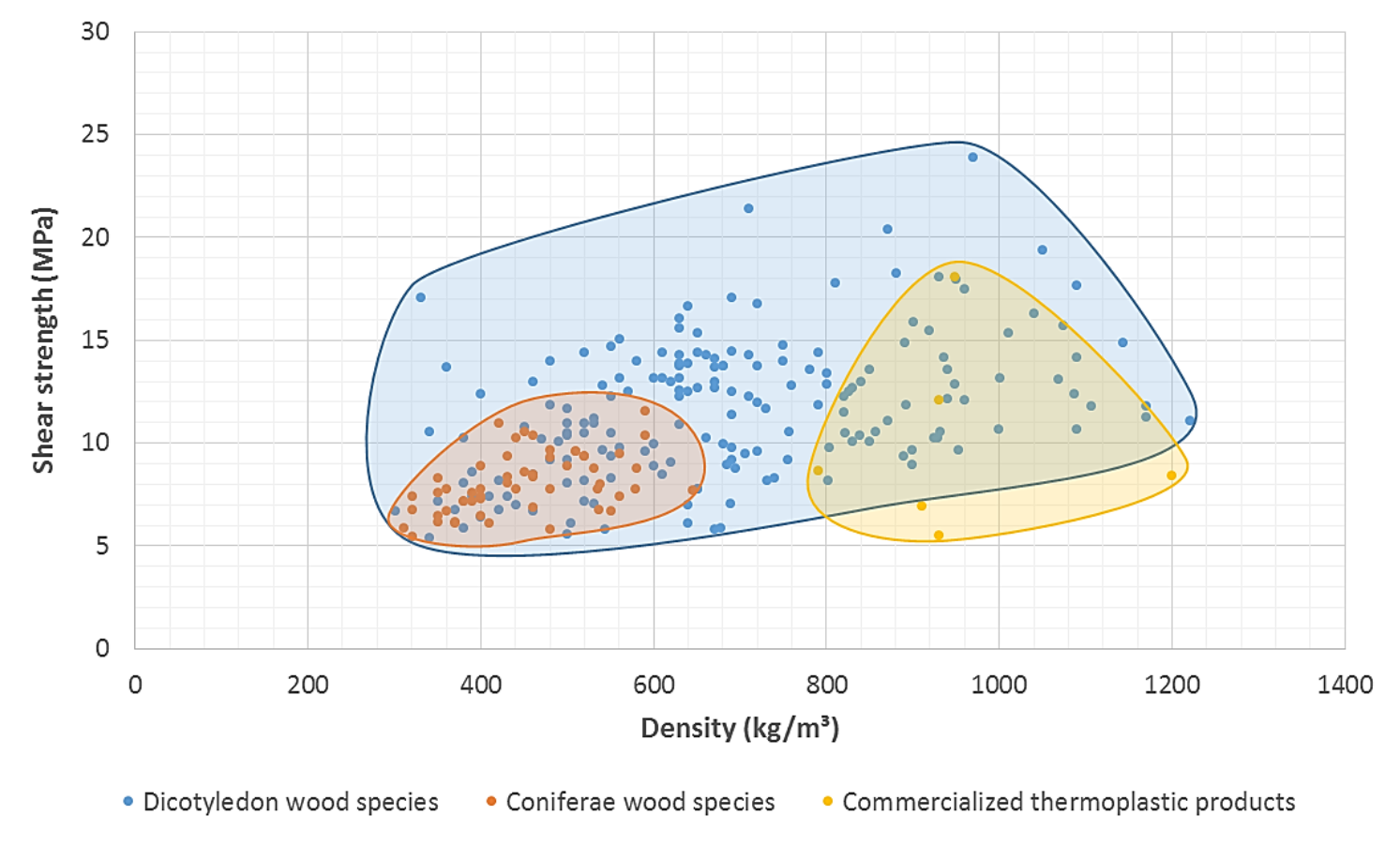

Figure 14 - Specific shear strengths of various wood species and thermoplastic products

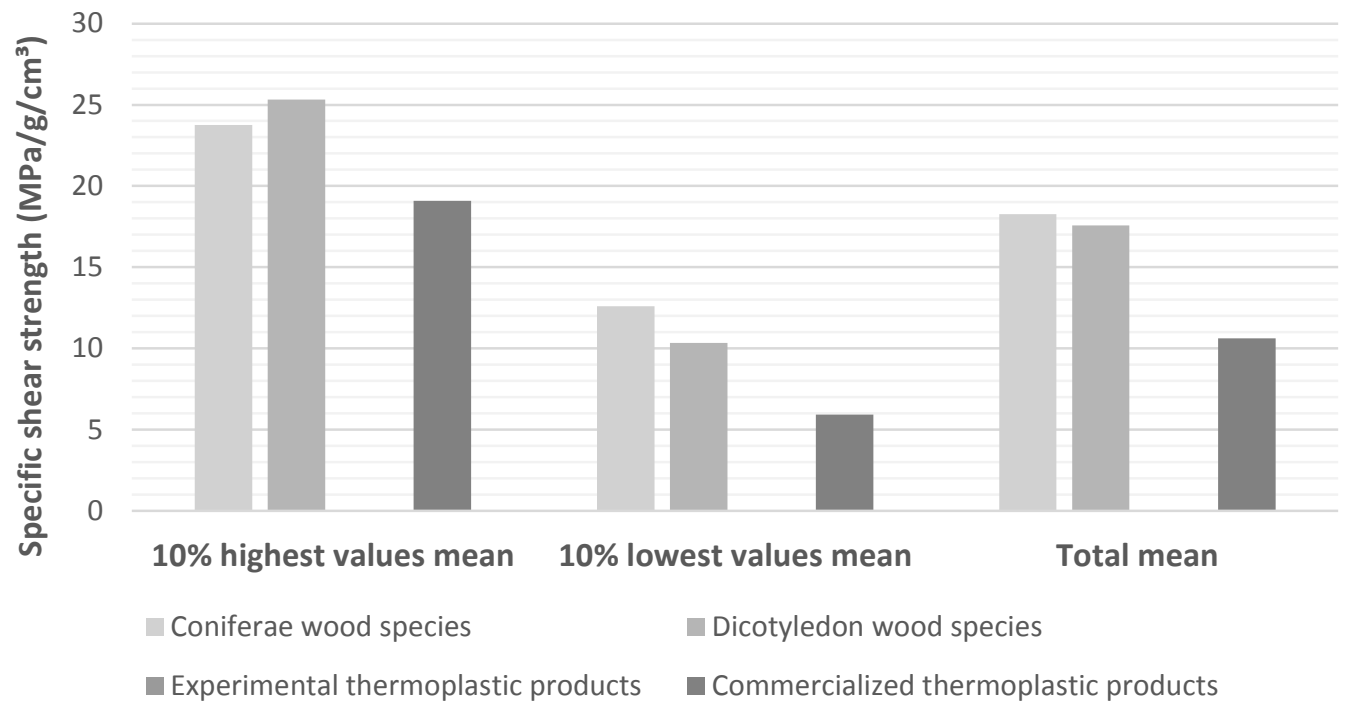

Note: the means of the materials' specific flexural strengths were calculated using data from 55 coniferae wood species, 179 dicotyledon wood species and 6 commercialized thermoplastic product compositions from 5 manufacturers. No papers were found on the shear strength of thermoplastic products. 


\section{Discussion}

Thermoplastic products showed great potential for functions in which wood lumber components are compressed or tensioned perpendicularly to the grain, as they have significantly higher specific strengths. Due to its better durability and maintainability, plastic lumber could be an alternative to wood lumber under such mechanical situations.

On the other hand, excluding strengths perpendicular to the grain, the specific compressive strength parallel to the grain is the only property in which the analysed thermoplastic products were, in general, superior to wood, and then, only for experimental products were. Commercialized thermoplastic products are still very far from achieving similar strength values to wood. However, few papers presenting the compressive strength of thermoplastic products have been found. This may cause a lack of data for specific researches, such this, and raise difficulties for the development of new thermoplastic composites and ways to use them, such as alternative building constructive systems and components, as also stated by Bajracharya et al. (2014) in study on glass fibre reinforced mixed plastic composites. In this respect, it should be noted that if the papers Carroll et al. (2001),
Chong et al. (2006), García et al. (2009) and Omar, Akil and Ahmad (2011), for example, had presented the composites densities, probably the specific compressive strength means (both parallel and perpendicular to grain) would be much lower, since these papers show composites' compressive values ranging from $3 \mathrm{MPa}$ to $40 \mathrm{MPa}$, while the plotted values range from $75 \mathrm{MPa}$ to $195 \mathrm{MPa}$. In spite of that, the extremely high compressive strength values shown by the plotted thermoplastic composites reveal their great potential for use in compressed elements.

For all other properties, wood is still more efficient than thermoplastic products and composites, i.e., to support a given load, thermoplastic-based elements need to be much larger and heavier than those of wood (Figure 15). This makes the design of structures and elements constructed with thermoplastic-based materials more complex, as they will occupy much more space or otherwise require many more components to satisfy a structural or semi-structural function, compared to wood. This is also a problem in the construction phase, as thermoplastic-based elements tend to be many times heavier than wood (in general, at least 2 times for elements under flexural loads (Figure 4) and 2.5 times for those under tensile loads parallel to the grain (Figure 6)), which make them difficult to transport and handle.

Figure 15 - Material specific properties: mean of $10 \%$ highest values. Unit: $\mathrm{MPa} / \mathrm{g} / \mathrm{cm}^{3}$

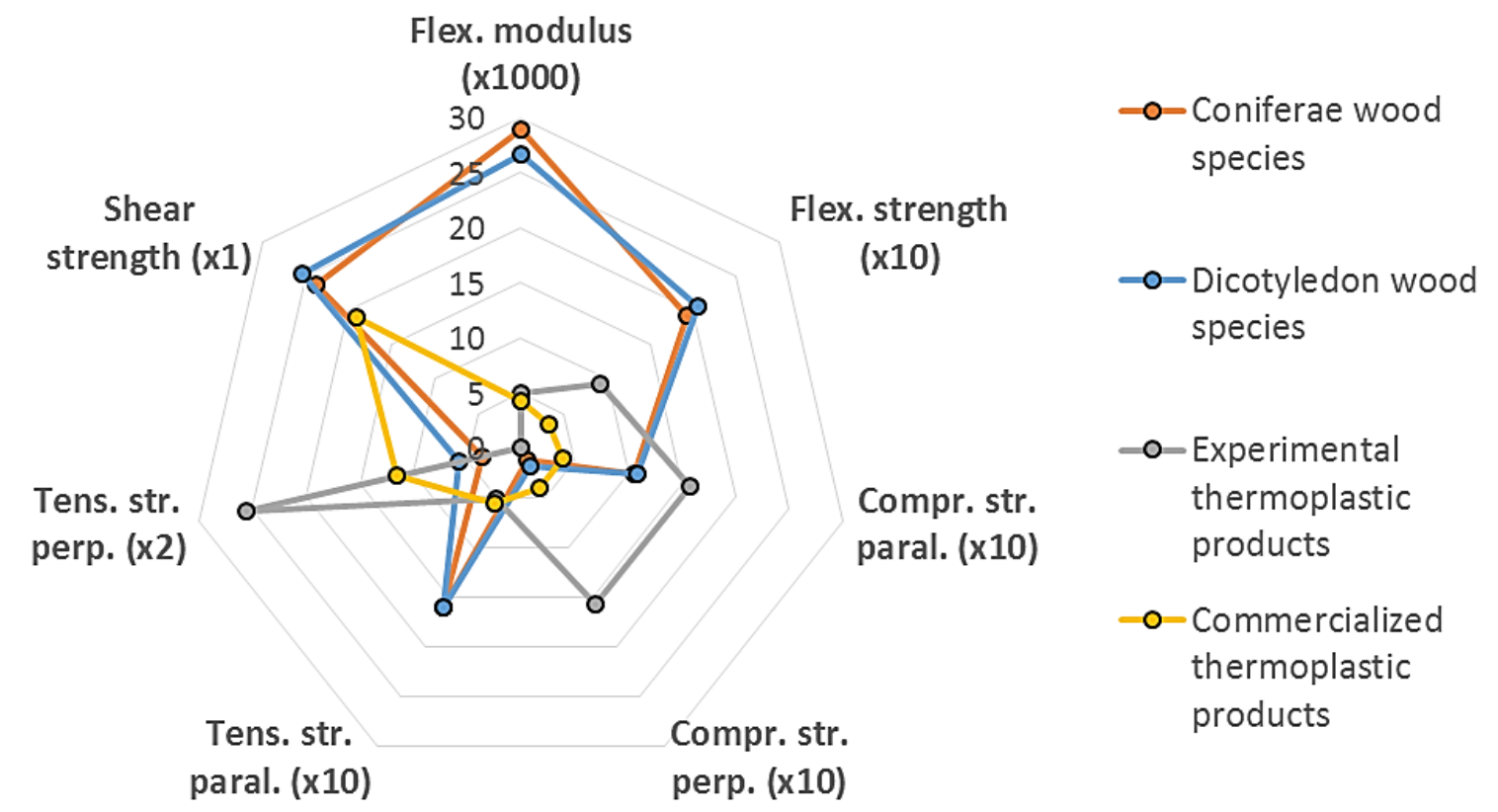


In this respect, Kozłowski and Władyka-Przybylak (2008) and Ndiaye, Gueye and Diop (2013) relates wood polymer composites and plastic composites reinforced by natural fibers, respectively, as having high strength to weight ratio. At least when compared to wood, this study found contrary results, although it embraces not only wood polymer composites and natural fiberthermoplastic composites. Actually, the finds of this study are in agreement to English and Falk (1996), which showed that polyolefins and wood plastic composites have higher density and lower flexural strength and modulus of elasticity (stiffness) than Southern pine and Douglas fir; and also in agreement to Benthien and Thoemen (2012), which related that wood-plastic composites panels have higher specific weight than woodbased panels. In this sense, the specific properties values calculated in this study indicates that researches on lighter and stronger materials (polymeric matrices and fillers), i.e, presenting better strength to density ratio, are necessary. The exhibited Ashby plots show that the densities of the wood species vary from approximately 300 $\mathrm{kg} / \mathrm{m}^{3}$ to $1200 \mathrm{~kg} / \mathrm{m}^{3}$, while those of the thermoplastic products vary from approximately $650 \mathrm{~kg} / \mathrm{m}^{3}$ to $1300 \mathrm{~kg} / \mathrm{m}^{3}$ (Figure 16). Among the 171 thermoplastic products compositions analysed, $152,89 \%$, have values greater than $900 \mathrm{~kg} / \mathrm{m}^{3}$, while among the 245 wood species (coniferae and dicotyledon) analysed, 31 have values greater than $900 \mathrm{~kg} / \mathrm{m}^{3}$, approximately 13\% (Figure 17). Moreover, although the use of coupling agents in the composites' formulation generally enhance their mechanical properties compared to composites made without them (STARK;
ROWLANDS, 2003; KARMARKAR et al., 2007; LEI et al., 2007; ADHIKARY; PANG; STAIGER, 2008, 2010; KIM et al., 2008; GWON et al., 2010; GUPTA et al., 2012; WANG et al., 2014; HONG et al., 2014; IGARZA et al., 2014; REN et al., 2015; IZZATI ZULKIFLI et al., 2015), the better interaction and adhesion between the polymeric matrix and the fillers provided by compatibilizers were not sufficient to produce composites with specific flexural properties and tensile strength parallel to grain even close to wood. For this purpose, effective ways to enhance their mechanical properties and, consequently, their specific properties, could be used concurrently, such as the selection of polymeric matrices with a determined melt flow index (LU et al., 2006; KIM et al., 2008; HOMKHIEW; RATANAWILAI; THONGRUANG, 2014; TABKHPAZ SARABI $e t$ al., 2014), the using of high-aspect-ratio fillers (STARK; ROWLANDS, 2003; KLYOSOV, 2007; ASHORI; NOURBAKHSH, 2010; LU; OZA, 2013) and the incorporation of fibres into the composites with a fixed orientation (JOSEPH et al., 2002; MIGNEAULT et al., 2009; YOO; SPENCER; PAUL, 2011; SINGH et al., 2014; VÄNTSI; KÄRKI, 2014), in spite of randomly oriented fibres.

For the specific flexural modulus, the thermoplastic-based products showed lower property values than wood, even considering the best ratios presented by the former compared to the worst ratios of the latter. This is a real limitation for their usage in civil engineering applications, as also stated by Bajracharya et al. (2014), as they exhibit a high deformation under small loads.

Figure 16 - Variation of the density of the wood species and thermoplastic products

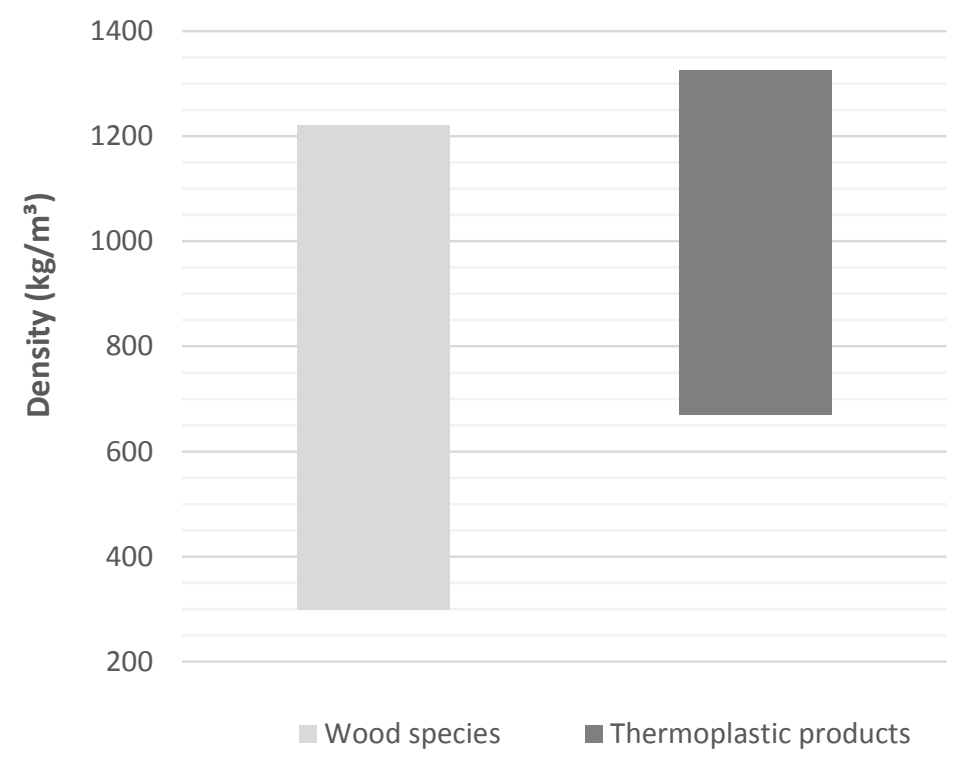

214 Dias, B. Z.; Alvarez, C. E. de 
Figure 17 - Percentage of wood species and thermoplastic products that present density value in the specified intervals

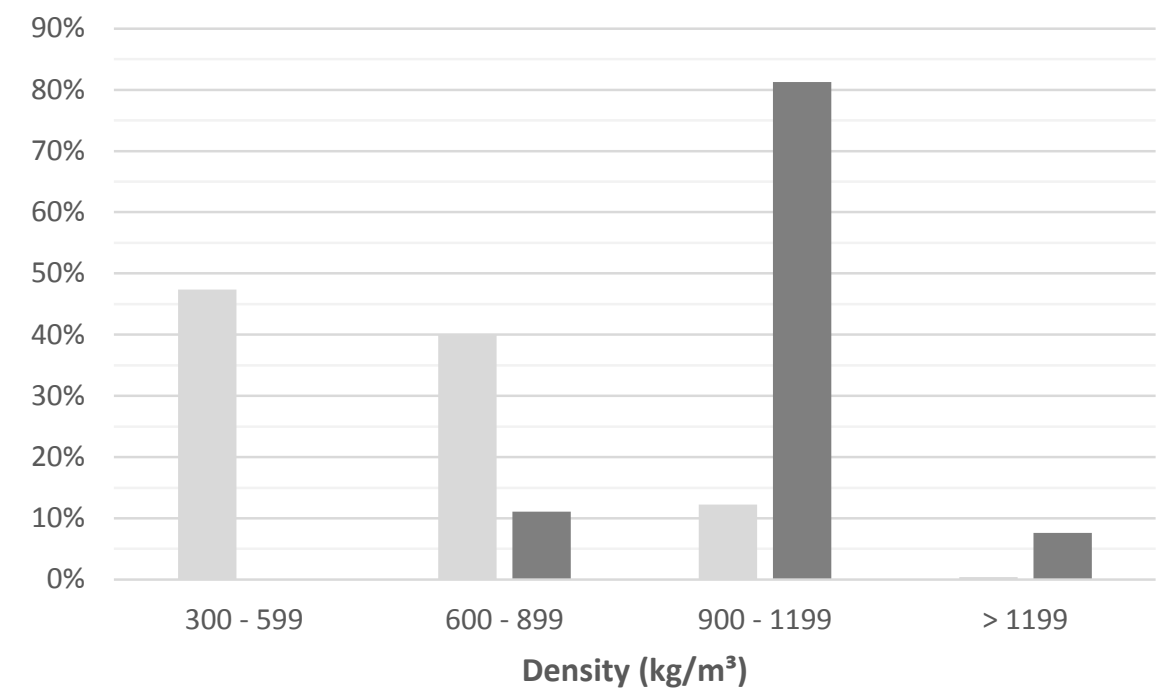

Wood species $\quad$ Thermoplastic products

Therefore, if it is intended that plastic lumber be a real alternative to wood lumber, not only for the materials' durability and maintenance issues but also the mechanical properties necessary to construct small buildings and structures, great advances are needed. In turn, as affirmed by English and Falk (1996, p. 193), "[...] it is expected that as more is learned about these areas, additional commercial applications for composites will develop.”.

\section{Conclusions}

Can thermoplastic-based products really substitute for wood lumber in structural or semi-structural functions? The results of this paper demonstrate that:

(a) thermoplastic products show great potential for use in functions where wood lumber components are compressed or tensioned perpendicularly to the grain, as the former have much greater specific strengths. Due to its superior durability and maintainability, plastic lumber could be an alternative to wood lumber under such mechanical situations;

(b) the extremely high values of compressive strength shown for the studied experimental thermoplastic composites, compared to wood, reveals their great potential use in compressed elements;

(c) regarding the thermoplastic-based products' specific flexural modulus, even considering their best ratios compared to the worst ratios of the wood species, the former still show lower property values, which can be translated to a high deformation in comparison to wood. This is a real limitation for their usage in civil engineering and building applications;

(d) studies on lighter and stronger materials (polymeric matrices and fillers), i.e., presenting a better strength to density ratio, are necessary. While only $13 \%$ of the 245 wood species show a density higher than $900 \mathrm{~kg} / \mathrm{m}^{3}$, approximately $89 \%$ of the 171 thermoplastic products have densities higher than that. This fact makes the design of structures and elements and the construction phase more complex; and

(e) very few data were found on the compressive and shear strength of plastic lumber and thermoplastic composites. There is a need for studies that focus on these properties to provide more data for a comprehensive comparison.

Thus, although it is inferior to wood in several mechanical properties, for some structural or semistructural functions, plastic lumber and thermoplastic composites are alternatives to wood lumber. In addition, the use of high-aspect-ratio fillers and specific fibre orientations are effective ways to produce thermoplastic composites with mechanical properties that are closer or similar to those of wood.

The next step of the research will be compare other properties, such as hardness and impact strength, of wood from coniferae and dicotyledon species from the Northern and Southern Hemispheres with 
that of commercialized and experimental thermoplastic-based product formulations.

\section{References}

ADHIKARY, K. B.; PANG, S.; STAIGER, M. P. Dimensional Stability and Mechanical Behaviour of Wood-Plastic Composites Based on Recycled and Virgin High-Density Polyethylene (HDPE). Composites Part B: Engineering, v. 39, n. 5, p. 807-815, jul. 2008.

ADHIKARY, K. B.; PANG, S.; STAIGER, M. P. Effects of the Accelerated Freeze-Thaw Cycling on Physical and Mechanical Properties of Wood Flour-Recycled Thermoplastic Composites. Polymer Composites, v. 31, p. 185-194, 2010.

ADHIKARY, K. B. et al. Effects of Lubricant Content on Extrusion Processing and Mechanical Properties of Wood Flour-High-Density

Polyethylene Composites. Journal of

Thermoplastic Composite Materials, v. 24, n. 2, p. 155-171, 2011.

\section{AMERICAN SOCIETY FOR TESTING AND}

MATERIALS. ASTM D638: standard test method for tensile properties of plastics. Philadelphia, 2014a.

AMERICAN SOCIETY FOR TESTING AND MATERIALS. ASTM D143: standard test method for small clear specimens of timber. Philadelphia, 2014b.

AMERICAN SOCIETY FOR TESTING AND

MATERIALS. ASTM D4761: standard test method for mechanical properties of lumber and wood-base structural material. Philadelphia, 2013.

AMERICAN SOCIETY FOR TESTING AND MATERIALS. ASTM D6272: standard test method for flexural properties of unreinforced and reinforced plastics and electrical insulating materials by four-point bending. Philadelphia, 2010a.

\section{AMERICAN SOCIETY FOR TESTING AND}

MATERIALS. ASTM D790: standard test method for flexural properties of unreinforced and reinforced plastics and electrical insulating materials. Philadelphia, 2010b.

ARAO, Y. et al. Improvement on Fire Retardancy of Wood Flour/Polypropylene Composites Using Various Fire Retardants. Polymer Degradation and Stability, v. 100, p. 79-85, 2014.

ASHBY, M. F. Materials Selection in Mechanical Design. $3^{\text {nd. }}$ ed. Oxford: Elsevier, 2005.
ASHORI, A.; NOURBAKHSH, A. Reinforced Polypropylene Composites: effects of chemical compositions and particle size. Bioresource Technology, v. 101, p. 2515-2519, 2010.

ASUKE, F. et al. Effects of Bone Particle on the Properties and Microstructure of

Polypropylene/Bone Ash Particulate Composites. Results in Physics, v. 2, p. 135-141, 2012.

AZWA, Z. N. et al. A Review on the Degradability of Polymeric Composites Based on Natural Fibres. Materials \& Design, v. 47, n. 5, p. 424-442, maio 2013.

BAJRACHARYA, R. M. et al. An Overview of Mechanical Properties and Durability of GlassFibre Reinforced Recycled Mixed Plastic Waste Composites. Materials \& Design, v. 62, p. 98112, out. 2014.

\section{BEDFORD TECHNOLOGY. SelectForce and} FiberForce HDPE Plastic Lumber Products Technical Manual for Decking/Boardwalk/Platform Applications. Disponível em:

<http://www.plasticboards.com/up/SelectForce \& FiberForce Technical Manual(3).pdf $>$. Acesso em: 24 mar. 2015.

BEG, M. D. H.; PICKERING, K. L. Reprocessing of Wood Fibre Reinforced Polypropylene composites: part I: effects on physical and mechanical properties. Composites Part A: Applied Science and Manufacturing, v. 39, n. 7, p. 1091-1100, jul. 2008.

BENTHIEN, J. T.; THOEMEN, H. Effects of Raw Materials and Process Parameters on the Physical and Mechanical Properties of Flat Pressed WPC Panels. Composites Part A: Applied Science and Manufacturing, v. 43, p. 570-576, 2012.

BOLIN, C. A.; SMITH, S. Life Cycle Assessment of ACQ-Treated Lumber With Comparison to Wood Plastic Composite Decking. Journal of Cleaner Production, v. 19, n. 6-7, p. 620-629, abr. 2011.

BOWYER, J. et al. Wood-Plastic Composite Lumber vs. Wood Decking: a comparison of performance characteristics and environmental attributes. Minneapolis: Dovetail Partners, Inc., 2010.

BUYUKSARI, U.; AYRILMIS, N.; AKBULUT, T. Compression Wood as a Source of Reinforcing Filler for Thermoplastic Composites. Journal of Applied Polymer Science, v. 123, p. 1740-1745, 2012. 
CARROLL, D. R. et al. Structural Properties of Recycled Plastic/Sawdust Lumber Decking Planks. Resources, Conservation and Recycling, v. 31, n. 3, p. 241-251, mar. 2001.

CARUS, M. et al. Wood-Plastic Composites (WPC) and Natural Fibre Composites (NFC): european and global markets 2012 and future trends. Hürth: Nova-Institut GmbH, 2014.

CHAVOOSHI, A. et al. MDF Dust/PP Composites Reinforced With Nanoclay: morphology, longterm physical properties and withdrawal strength of fasteners in dry and saturated conditions. Construction and Building Materials, v. 52, p. 324-330, 2014.

CHEVALI, V. S.; DEAN, D. R.; JANOWSKI, G. M. Effect of Environmental Weathering on Flexural Creep Behavior of Long Fiber-Reinforced Thermoplastic Composites. Polymer Degradation and Stability, v. 95, n. 12, p. 2628-2640, dez. 2010.

CHONG, M. H. et al. Fire-Retardant Plastic Material From Oyster-Shell Powder and Recycled Polyethylene. Journal of Applied Polymer Science, v. 99, p. 1583-1589, 2006.

\section{ECO-TECH PLASTICS. Duramax Structural}

Lumber. Disponível em: <http://www.ecotechplastics.com/uploads/Eco-

Tech_DuraMax.pdf >. Acesso em: 24 mar. 2015.

ENGLISH, B. W.; FALK, R. H. Factors That Affect the Application of Woodfiber-Plastic Composites. In: FOREST PRODUCTS SOCIETY, Anais... 1996.

FABIYI, J. S.; MCDONALD, A. G. Effect of Wood Species on Property and Weathering Performance of Wood Plastic Composites. Composites Part A: Applied Science and Manufacturing, v. 41, n. 10, p. 1434-1440, out. 2010.

GARCÍA, M. et al. Wood-Plastics Composites With Better Fire Retardancy and Durability Performance. Composites Part A: Applied Science and Manufacturing, v. 40, n. 11, p. 1772-1776, nov. 2009.

GUPTA, A. K. et al. Mechanical, Thermal Degradation, and Flammability Studies on Surface Modified Sisal Fiber Reinforced Recycled Polypropylene Composites. Advances in Mechanical Engineering, p. 1-13, 2012.

GWON, J. G. et al. Effects of Chemical Treatments of Hybrid Fillers on the Physical and Thermal Properties of Wood Plastic Composites. Composites Part A: Applied Science and Manufacturing, v. 41, p. 1491-1497, 2010.
HAIDER, A.; EDER, A. Markets, Applications, and Processes for Wood Polymer Composites (WPC) in Europe. In: PROCESSING TECHNOLOGIES FOR THE FOREST AND BIOBASED PRODUCTS INDUSTRIES, 1., Kuchl, 2010. Anais..., Kuchl: Salzburg University of Applied Sciences, 2010.

HEMMATI, F.; GARMABI, H. A Study on Fire Retardancy and Durability Performance of Bagasse Fiber/Polypropylene Composite for Outdoor Applications. Journal of Thermoplastic Composite Materials, v. 26, n. 8, p. 1041-1056, 2012.

HOMKHIEW, C.; RATANAWILAI, T.; THONGRUANG, W. Effects of Natural Weathering on the Properties of Recycled Polypropylene Composites Reinforced With Rubberwood Flour. Industrial Crops and Products, v. 56, p. 52-59, maio 2014.

HONG, H. et al. Significant Improvement in Performance of Recycled Polyethylene/Wood Flour Composites by Synergistic Compatibilization at Multi-Scale Interfaces. Composites Part A: Applied Science and Manufacturing, v. 64, p. 90-98, 2014.

IGARZA, E. et al. Structure-Fracture Properties Relationship for Polypropylene Reinforced With fly Ash With and Without Maleic Anhydride Functionalized Isotactic Polypropylene as Coupling Agent. Materials \& Design, v. 55, p. 85-92, mar. 2014.

IZZATI ZULKIFLI, N. et al. Mechanical Properties and Failure Modes of Recycled Polypropylene/Microcrystalline Cellulose Composites. Materials \& Design, v. 69, p. 114123, mar. 2015.

JOSEPH, P. V. et al. Environmental Effects on the Degradation Behaviour of Sisal Fibre Reinforced Polypropylene Composites. Composites Science and Technology, v. 62, n. 10-11, p. 1357-1372, ago. 2002.

KARMARKAR, A. et al. Mechanical Properties of Wood-Fiber Reinforced Polypropylene Composites: effect of a novel compatibilizer with isocyanate functional group. Composites Part A: Applied Science and Manufacturing, v. 38, n. 2, p. 227-233, 2007.

KIM, S.-J. et al. Mechanical Properties of Polypropylene/Natural Fiber Composites: comparison of wood fiber and cotton fiber. Polymer Testing, v. 27, n. 7, p. 801-806, out. 2008. 
KIZILTAS, A. et al. Mechanical Properties of Microcrystalline Cellulose (MCC) Filled Engineering Thermoplastic Composites. Journal of Polymers and the Environment, v. 22, n. 3, p. 365-372, 2014.

KLYOSOV, A. A. Wood-Plastic Composites. Hoboken: John Wiley \& Sons, Inc., 2007.

KOZŁOWSKI, R.; WŁADYKA-PRZYBYLAK, M. Review: flammability and fire resistance of composites reinforced by natural fibers. Polymers for Advanced Technologies, v. 19, p. 446-453, 2008.

KUO, P.-Y. et al. Effects of Material Compositions on the Mechanical Properties of Wood-Plastic Composites Manufactured by Injection Molding. Materials \& Design, v. 30, n. 9, p. 3489-3496, out. 2009.

LEI, Y. et al. Preparation and Properties of Recycled HDPE/Natural Fiber Composites. Composites Part A: Applied Science and Manufacturing, v. 38, n. 7, p. 1664-1674, jul. 2007.

LEU, S.-Y. et al. Optimized Material Composition to Improve the Physical and Mechanical Properties of Extruded Wood-Plastic Composites (WPCs). Construction and Building Materials, v. 29, p. 120-127, abr. 2012.

LU, J. Z. et al. The Influences of Fiber Feature and Polymer Melt Index on Mechanical Properties of Sugarcane Fiber/Polymer Composites. Journal of Applied Polymer Science, v. 102, n. 6, p. 56075619, 2006.

LU, N.; OZA, S. A Comparative Study of the Mechanical Properties of Hemp Fiber With Virgin and Recycled High Density Polyethylene Matrix. Composites Part B: Engineering, v. 45, n. 1, p. 1651-1656, fev. 2013.

MIGNEAULT, S. et al. Effects of Processing Method and Fiber Size on the Structure and Properties of Wood-Plastic Composites.

Composites Part A: Applied Science and Manufacturing, v. 40, n. 1, p. 80-85, 2009.

MORRELL, J. J. et al. Durability of Wood-Plastic Composites. In: INTERNATIONAL CONFERENCE ON WOOD \& BIOFIBER PLASTIC COMPOSITES AND CELLULOSE NANOCOMPOSITES SYMPOSIUM, 10., Madison, 2010. Proceedings... Madison: Forest Products Society, 2010.

NAJAFI, S. K.; HAMIDINA, E.; TAJVIDI, M. Mechanical Properties of Composites From Sawdust and Recycled Plastics. Journal of Applied Polymer Science, v. 100, n. 5, p. 36413645, 5 jun. 2006.
NAJAFI, S. K.; KORDKHEILI, H. Y. Effect of Sea Water on Water Absorption and Flexural Properties of Wood-Polypropylene Composites. European Journal of Wood and Wood Products, v. 69, n. 4, p. 553-556, 12 jan. 2011.

NAUMANN, A.; STEPHAN, I.; NOLL, M. Material Resistance of Weathered Wood-Plastic Composites Against Fungal Decay. International Biodeterioration \& Biodegradation, v. 75, p. 2835, 2012.

NDIAYE, D.; GUEYE, M.; DIOP, B. Characterization, Physical and Mechanical Properties of Polypropylene/Wood-Flour Composites. Arabian Journal for Science and Engineering, v. 38, n. 1, p. 59-68, 2013.

NOURBAKHSH, A.; ASHORI, A. Preparation and Properties of Wood Plastic Composites Made of Recycled High-Density Polyethylene. Journal of Composite Materials, v. 43, n. 8, p. 877-883, 1 abr. 2009.

OMAR, M. F.; AKIL, H. M.; AHMAD, Z. A. Static and Dynamic Compressive Properties of Mica/Polypropylene Composites. Materials Science and Engineering A, v. 528, p. 15671576, 2011.

OZEN, E. et al. Natural Fiber Blend-Nylon 6 Composites. Polymer Composites, v. 34, p. 544553, 2013.

RAJA, V. L.; KUMARAVEL, A. Studies on Physical and Mechanical Properties of Silica Fume-Filled Nylon 66 Polymer Composites for Mechanical Components. Polymers \& Polymer Composites, v. 23, n. 6, p. 427-433, 2015.

REN, Y. et al. Evaluation of Intumescent Fire Retardants and Synergistic Agents For Use in Wood Flour/Recycled Polypropylene Composites. Construction and Building Materials, v. 76, p. 273-278, 2015.

SINGH, S. et al. Tensile and Flexural Behavior of Hemp Fiber Reinforced Virgin-Recycled HDPE Matrix Composites. Procedia Materials Science, v. 6, p. 1696-1702, 2014.

STARK, N. M. Effect of Weathering Variables on the Lightness of High-Density Polyethylene Woodflour Composites. In: INTERNATIONAL CONFERENCE ON WOODFIBER-PLASTIC COMPOSITES, MADISON, 8., Madison, 2005 Proceedings... Madison: Forest Products Society, 2005.

STARK, N. M. Effect of Weathering Cycle and Manufacturing Method on Performance of Wood Flour and High-Density Polyethylene Composites. Journal of Applied Polymer Science, v. 100, n. 4, p. 3131-3140, 15 maio 2006. 
STARK, N. M.; ROWLANDS, R. E. Effects of Wood Fiber Characteristics on Mechanical Properties of Wood/Polypropylene Composites. Wood and Fiber Science, v. 35, n. 2, p. 167-174, 2003.

STRÖMBERG, E.; KARLSSON, S. The Effect of Biodegradation on Surface and Bulk Property Changes of Polypropylene, Recycled Polypropylene and Polylactide Biocomposites. International Biodeterioration \& Biodegradation, v. 63, n. 8, p. 1045-1053, dez. 2009.

TABKHPAZ SARABI, M. et al. Effect of Polymeric Matrix Melt Flow Index in Reprocessing Extruded Wood-Plastic Composites. Journal of Thermoplastic Composite Materials, v. 27, n. 7, p. 881-894, 2014.

VÄNTSI, O.; KÄRKI, T. Utilization of Recycled Mineral Wool as Filler in Wood-Polypropylene Composites. Construction and Building Materials, v. 55, p. 220-226, 2014.

WANG, K. et al. Dynamic Behavior and Flame Retardancy of HDPE/Hemp Short Fiber Composites: effect of coupling agent and fiber loading. Composite Structures, v. 113, p. 74-82, jul. 2014.
WEI, L. et al. Effects of Wood Fiber Esterification on Properties, Weatherability and Biodurability of Wood Plastic Composites. Polymer Degradation and Stability, v. 98, p. 1348-1361, 2013.

WINANDY, J. E.; STARK, N. M.; CLEMONS, C. M. Considerations in Recycling of Wood-Plastic Composites. In: GLOBAL WOOD AND NATURAL FIBRE COMPOSITES SYMPOSIUM, 5., Kassel, 2004. Proceedings... Kassel, 2004.

YEMELE, M. C. N. et al. Effect of Bark Fiber Content and Size on the Mechanical Properties of Bark/HDPE Composites. Composites Part A: Applied Science and Manufacturing, v. 41, n. 1, p. 131-137, 2010.

YOO, Y.; SPENCER, M. W.; PAUL, D. R. Morphology and Mechanical Properties of Glass Fiber Reinforced Nylon 6 Nanocomposites.

Polymer, v. 52, p. 180-190, 2011.

YOUSSEF, A. M.; EL-GENDY, A.; KAMEL, S. Evaluation of Corn Husk Fibers Reinforced Recycled Low Density Polyethylene Composites. Materials Chemistry and Physics, v. 152, p. 2633, 2015.

\section{Acknowledgements}

This work was supported by the Brazilian agency Coordenação de Aperfeiçoamento de Pessoal de Nível Superior (CAPES).

\author{
Revista Ambiente Construído \\ Associação Nacional de Tecnologia do Ambiente Construído \\ Av. Osvaldo Aranha, $99-3^{\circ}$ andar, Centro \\ Porto Alegre - RS - Brasil \\ CEP $90035-190$ \\ Telefone: +55 (51) 3308-4084 \\ Fax: +55 (51) 3308-4054 \\ www.seer.ufrgs.br/ambienteconstruido \\ E-mail: ambienteconstruido@ufrgs.br
}

